\section{A campanha contra a broca-do-café em São Paulo (1924-1927)*}

\section{The campaign against the coffee borer in São Paulo (1924-1927)}

André Felipe Cândido da Silva

Mestre em História das Ciências pelo Programa de Pós-Graduação da Casa de Oswaldo Cruz, Rua Cardeal Dom Sebastião Leme, 125, ap. s402 22040-012 Rio de Janeiro - RJ - Brasil andre_csilva@ig.com.br
SILVA, A. F. C. da: A campanha contra a broca-do-café em São Paulo (1924-1927). História, Ciências, Saúde - Manguinhos, Rio de Janeiro, v. 13, n. 4, p. 957-93, out.-dez. 2006.

Quando o café constituía a principal riqueza brasileira e São Paulo detinha a liderança absoluta na sua produção e comércio, uma praga veio colocar sob ameaça toda aquela pujança econômica. Conhecida como brocado-café, era causada por um minúsculo inseto aparecido em fazendas de Campinas. De lá partiu a notificação ao governo paulista, em maio de 1924. A gravidade da situação levou o governo estadual a compor uma comissão científica chefiada por Arthur Neiva, responsável por levar a cabo o plano de combate. A campanha contra a broca combinou a implementação de um vigoroso aparato de pesquisa e fiscalização com amplo trabalho de divulgação científica, que lançou mão de estratégias vanguardistas de difusão, como o cinema. Em fins de 1927, a Comissão foi formalmente extinta após a criação de uma instituição permanente de pesquisa agrícola: 0 Instituto Biológico de Defesa Agrícola e Animal.

PALAVRAS-CHAVE: economia cafeeira; broca-do-café; comissão científica; pragas agrícolas.

SILVA, A. F. C. da: The campaign against the coffee borer in São Paulo (1924-1927). História, Ciências, Saúde - Manouinhos, Rio de Janeiro, v. 13, n. 4, p. 957-93, Oct.-Dec. 2006.

When coffee was Brazil's chief source of wealth and São Paulo was the absolute leader in its production and trade, a plague suddenly came to threaten this mighty economic asset. The cause was a tiny insect called the coffee borer, which began showing up on plantations in the Campinas area. The São Paulo state government learned of the pest in May 1924 via news from Campinas. The situation was so serious that the state government formed a scientific commission, headed by Arthur Neiva, who was to lead the battle against the borer. The ensuing campaign put in place a sound system of research and surveillance, complemented by broad-reaching scientific education that relied on such vanguard tools as cinema. In late 1927, the Commission was officially dissolved, following creation of a permanent agricultural research center: the Instituto Biológico de Defesa Agrícola e Animal (Biological Institute for Agricultural and Animal Defense).

KEYWORDS: coffee economy; coffee borer; scientific commission; agricultural pests. 
Este trabalho é parte da dissertação de mestrado apresentada ao Programa de Pós-Graduação em História das Ciências da Casa de Oswaldo Cruz/Fiocruz, defendida em 30 de março de 2004 e intitulada Ciência nos cafezais: a campanha contra a broca-do-café em São Paulo (1924-1929).

\section{O cenário e o vilão: a cafeicultura paulista e as primeiras notícias sobre a praga}

Na década de 1920 o café era o esteio da economia brasileira, contribuindo com 70 por cento das exportações brasileiras. São Paulo, de longe o maior produtor do país, controlava quase a metade do comércio cafeeiro mundial (Love, 1982, p. 63-5). A supremacia paulista na produção do café advinha da expansão continuada das frentes agrícolas rumo ao oeste desde o último quartel do século XIX. Enquanto a produção do vale do Paraíba entrava em decadência com a crise de mão-de-obra, largamente baseada na utilização do trabalho escravo e em métodos predatórios de cultivo, floresciam no oeste paulista novas áreas produtoras, favorecidas por condições ecológicas adequadas ao cultivo da rubiácea.

Essa frente de expansão foi impulsionada pelas ferrovias: a partir de 1870, as novas áreas desbravadas pelos cafeicultores e os trilhos marchariam em ritmo praticamente simultâneo (Lapa, 1983, p.3). Além de oferecer mais segurança, rapidez e eficiência no transporte, as ferrovias possibilitaram maior distanciamento entre as zonas produtoras e o porto de escoamento. Seus cursos foram ditados pelo interesse em abarcar novas zonas produtoras surgidas do avanço da fronteira agrícola, sempre em busca de terras virgens e férteis. Dos troncos ferroviários principais, implantados por companhias como a Paulista e a Mogiana, partiram inúmeras ramificações, verdadeiras estradas 'cata-café' que iam até os novos núcleos produtores (Mattos, 1990).

As ferrovias permitiram também grande afluência de trabalhadores estrangeiros para as novas zonas produtoras. Desde a crise de mão-de-obra instaurada após o fim do tráfico de escravos, em 1850, e a emancipação dos cativos, em 1888, os fazendeiros do oeste lançaram mão do trabalhador livre estrangeiro nas lavouras. A corrente imigratória ganhara impulso a partir de 1870, recrudescendo com a República, quando a elite econômica paulista teve maior flexibilidade para atuar em benefício de seus interesses econômicos. Entre 1889 e 1930, mais de dois milhões de imigrantes desembarcaram em São Paulo (dos quais um milhão era de origem italiana), e dois terços do total foram direcionados para as fazendas de café (Love, 1982, p. 27; Silva, 1995, p. 50).

O fenômeno urbano acompanhou a expansão do café, disseminando cidades pelo interior paulista. Os cafeicultores do oeste, de mentalidade capitalista, assumiam hábitos urbanos e deixavam suas fazendas, transformadas unicamente em unidades de produção, para habitar luxuosos palacetes nas principais cidades do estado. A capital deixou de ser a acanhada cidade colonial para se transmutar na 'metrópole do café', em súbito processo de urbanização desde o final do século XIX (Love, 1982). Santos tornou-se o principal porto 
de escoamento das exportações brasileiras graças ao café, base de seu crescimento e modernização. A vocação urbana dos fazendeiros do oeste foi uma face das transformações mais profundas ocorridas na economia e sociedade cafeeiras, entre as quais a diversificação e complexificação das atividades ligadas direta ou indiretamente ao café. $O$ incremento da comercialização acarretou o surgimento de diversos intermediários, como as casas comissárias e exportadoras estabelecidas na praça de Santos. O 'capital cafeeiro' gerou um complexo de atividades e serviços, abarcando os capitais agrário, industrial, mercantil e financeiro (Silva, 1995, p. 54).

A primazia de São Paulo na produção cafeeira nacional, a partir da última década do século XIX, foi acompanhada da hegemonia política de suas elites sobre o aparelho estatal republicano. A expansão contínua das frentes pioneiras e a disponibilidade de mãode-obra garantida pela política imigratória, aliadas às vantagens comerciais proporcionadas pelo café, provocaram o crescimento da oferta e a conseqüente superprodução (Furtado, 1968, p. 188). O domínio político das oligarquias paulistas possibilitou a implementação de seguidos programas de defesa econômica sob a tutela do governo. Tais políticas, das quais a instituída pelo Convênio de Taubaté, em 1906, foi a mais conhecida, consistiram no controle da oferta de modo a estabilizar os preços (ibidem, p. 189-90).

A manutenção de bons preços, por sua vez, incentivava a expansão continuada das plantações e a reiteração das crises de superprodução. A queda nas exportações, associada à desorganização do comércio internacional durante a Primeira Guerra Mundial, logo foi superada graças aos programas de defesa econômica dos governos paulista e federal. Em 1920, o café alcançava novamente bons preços, insuflando a prosperidade do complexo econômico firmado pela agricultura, indústria, serviços públicos e imprensa. São Paulo agora adquiria supremacia no comércio cafeeiro mundial graças às pragas que assolaram seus maiores concorrentes: as colônias holandesas do sudeste asiático (Love, 1982, p. 65).

A complexidade da economia cafeeira na década de 1920 refletiase no posicionamento político das elites, cujos meios de expressão incluíam múltiplas agremiações agrícolas. Havia a Sociedade Paulista de Agricultura, fundada em 1902 e identificada com os interesses governistas; a Sociedade Rural Brasileira, a mais influente de todas, fundada em 1919, e a Liga Agrícola Brasileira - LAB, organizada em 1921 pelos produtores do interior de São Paulo.

Em 1924, quando o café e todas as atividades a ele associadas 'pulsavam' com todo o vigor, uma praga ameaçou fazer ruir todo aquele portentoso complexo econômico: um inseto broqueador das cerejas do café, que inutilizava os grãos e mostrava grande potencial de devastação. A praga que irrompeu nos cafezais de Campinas talvez fosse a mesma que assolara a cafeicultura nas colônias 
holandesas de Java e Sumatra e que, a princípio, beneficiara consideravelmente as posições do Brasil no mercado mundial.

A apreensão tomou conta da cafeicultura paulista quando a praga foi noticiada, em 30 de maio de 1924, pelo jornal O Estado de S. Paulo, periódico de grande destaque na época, porta-voz dos interesses da Sociedade Rural Brasileira, da qual fazia parte seu presidente Júlio de Mesquita Filho. A notícia baseava-se em notificação feita cerca de 15 dias antes por um fazendeiro de Campinas ao secretário de Agricultura do governo de Carlos de Campos (1924-1927), Gabriel Ribeiro dos Santos. Este enviara àquela cidade o diretor de Agricultura, Adalberto Queiroz Telles, acompanhado do entomologista Adolpho Hempel. Em uma das fazendas, um colono mostrara-lhes um saco de café em coco que deveria pesar 45 quilos mas ficara reduzido a 16 quilos (Neiva, 1928, p. 3-4). De volta a São Paulo, Hempel procurou classificar o inseto, mas por falta de biblio-grafia especializada verificou apenas que se enquadrava no gênero Stephanoderes.

Diante da gravidade do caso, a Secretaria de Agricultura paulista solicitou ao Ministério da Agricultura a convocação de Arthur Neiva e Ângelo Moreira da Costa Lima para identificar o inseto e indicar meios de combatê-lo - ambos entomologistas de renome, com experiências prévias em pragas agrícolas. Costa Lima era professor de entomologia agrícola da Escola Superior de Agricultura e Medicina Veterinária e diretor do Serviço de Defesa Sanitária Vegetal do Ministério da Agricultura, órgão responsável pelo atendimento em casos de epifitias (Bloch, 1968, p. 104).

A notícia publicada em $O$ Estado de $S$. Paulo repercutiu nos principais jornais do país, reproduzindo-se até mesmo o tom alarmista e calamitoso da notícia original. Embora realçasse a gravidade do caso, o periódico paulista assegurava que o mal era antigo e a progressão da praga, lenta, havendo portanto tempo suficiente para que fossem tomadas as providências cabíveis (Notas e Informações, 30.5.1924).

A celeuma instaurada pelos informes dos jornais fomentou a curiosidade de pessoas que, de várias localidades, dirigiram-se 'em romaria' a Campinas para observar pessoalmente a praga. A sua vinculação à lavoura campineira provocou a reação de grupos daquele município, preocupados com sua estigmatização e com possíveis medidas de intervenção em sua economia. Periódicos locais, como o Diário do Povo, foram o canal de expressão do descontentamento da "lavoura mais antiga e importante do estado", qualificando as notícias d'O Estado como "ruidosa celeuma", "excesso de zelo e inútil espalhafato" (Diário do Povo, 2.6.1924). À acusação de que Campinas era o foco disseminador da praga, com evidentes conseqüências para seu comércio, o Diário do Povo contrapunha a afirmação de que o mal grassava em outras localidades (ibidem). 
O posicionamento de Campinas naquela conjuntura foi análogo ao de cidades do interior paulista quando da irrupção de epidemias de febre amarela na década de 1890 (Telarolli Jr., 1996b). Nos jornais locais, os grupos regionais saem em defesa de seus interesses e veiculam sua versão dos acontecimentos, na maioria das vezes com o intuito de amenizar a gravidade dos fatos.

\section{A contenda sobre a responsabilidade pela praga}

Segundo O Estado de S. Paulo a praga era antiga, informação corroborada pelo Diário do Povo, o qual admitiu, até mesmo, que a 'novidade' não havia provocado entre os lavradores de Campinas a "menor impressão" (Diário do Povo, 01.6.1924). O Estado havia se referido ao "perigo do silêncio da imprensa". De fato, tanto esta como os lavradores campineiros mantiveram silêncio sobre o caso por receio das conseqüências da denúncia de uma grave praga em seus cafeeiros. Embora o inseto estivesse abrigado nos cafezais de Campinas havia cerca de dez anos, somente nos dois últimos a infestação começara a atingir níveis alarmantes. Os lavradores haviam subestimado o potencial de ataque do parasita por este ser lento em sua expansão. Em 1922, um fazendeiro teria notificado ao Instituto Agronômico de Campinas - IAC, estabelecimento oficial de pesquisa agrícola, a ocorrência da praga em seus cafeeiros.

Essa informação motivou uma calorosa contenda no seio da imprensa: se o inseto era de origem estrangeira, como havia sido introduzido em São Paulo? Ademais, se dois anos antes o governo fora inteirado da existência da praga, por que não tomara nenhuma providência para combatê-la? As acusações recaíram sobre o IAC e sobre seu diretor, Jean Jules Arthaud Berthet. O fundamento da acusação repousava no fato de que a maior virulência da praga era observada em espécies exóticas de café importadas por aquela instituição.

Berthet veio a público defender-se das acusações. Alegou que em 1922 o IAC publicara nota sobre a praga no Boletim de Agricultura, informe oficial da secretaria paulista. Acusações partiam de todos os lados, acuando o cientista. Seus argumentos foram ponto a ponto contestados por seus delatores, entre os quais aquele mesmo fazendeiro que fizera a notificação anos antes. O comportamento de Berthet foi considerado negligente, sendo comparado ao 'crime' de alguém se calar de posse da informação de que o reservatório de água de uma cidade estava infestado de micróbios (O Estado de $S$. Paulo, 10.6.1924). Recorria-se à experiência aterradora das epidemias a fim de dimensionar para a opinião pública a amplitude da irresponsabilidade de Berthet.

A contenda ganhou status de controvérsia científica ao colocar-se em questão se o inseto por ele mencionado no Boletim de Agricultura, em 1922, era o agente que agora atacava a lavoura cafeeira paulista. 
O parasita a que se referia o diretor do IAC havia sido classificado como espécienova pelo entomologista da instituição, Campos Novaes, e atacava o galho do cafeeiro, e não o fruto, como fazia o Stephanoderes (Novaes, 1922). Porém, o debate assumia conotação política: Washington Luís, presidente do estado em 1922, graças à sua inação, teria sido também responsável pelo revés que agora sofria a cafeicultura paulista.

Outra evidência também envolveu Berthet com a praga. Comunicação firmada por ele no Boletim de Agricultura em 1913 tratava de inseto da família dos Ipídeos, à qual pertence o Stephanoderes (Berthet, 1913). De acordo com Berthet, o material de onde proviera o inseto havia sido destruído, mas "segundo versão corrente em Campinas" (Neiva, 1928, p. 20), fora atirado ao lixo rotineiramente utilizado por fazendeiros de lá como adubo.

A gestão do agrônomo francês à frente do IAC, iniciada em 1907, foi alvo de ataques severos, questionando-se não só sua competência profissional como sua idoneidade pessoal. Jocosamente, o IAC era apelidado "Institut Agronomic pour études des plantes et des insectes exotiques" (O Estado de S. Paulo, 14.6.1924), numa alusão aos rumores de que Berthet favorecia pesquisadores franceses em detrimento dos brasileiros. Prova disso seria que a França teria sido o único país a legislar contra a broca-do-café antes de o alarme soar nos jornais paulistas, ou seja, os franceses foram informados da ocorrência da praga no Brasil, podendo se precaver contra sua introdução (Freire, 1928, p. 155; Neiva, 1928, p. 21). Episódios anteriores foram recuperados por aqueles que procuravam lançar descrédito sobre o diretor do IAC, finalmente afastado do cargo no final de 1924 após inquérito administrativo (Relatório apresentado ao Dr. Carlos de Campos, presidente do estado, por Gabriel Ribeiro dos Santos, secretário da Agricultura, Comércio e Obras Públicas - ano de 1924, p. 36).

O IAC não foi a única instituição criticada por aqueles que buscavam culpados pela introdução da praga em São Paulo. O aparato de defesa fitossanitária do Ministério da Agricultura, responsável pela inspeção de plantas importadas, foi acusado de não executar adequadamente suas funções, já que a broca-do-café era apenas uma entre as inúmeras pragas e doenças que assolavam as lavouras brasileiras. O Instituto Biológico de Defesa Agrícola e Animal era o órgão do Ministério da Agricultura, criado em 1921, encarregado da vigilância fitossanitária. Dirigido por Carlos Moreira, entomologista que anos antes chefiara, no Museu Nacional, o Laboratório de Entomologia Agrícola, o Instituto Biológico era composto pelos serviços de fitopatologia, entomologia e vigilância sanitária vegetal. O exercício de polícia fitossanitária era feito por postos de fiscalização estabelecidos nos portos. Os estudos teóricos ficavam a cargo dos serviços de fitopatologia e entomologia, ao 
passo que os dispositivos práticos eram de responsabilidade da vigilância sanitária vegetal.

As críticas direcionadas a este instituto estavam relacionadas ao surgimento, concomitante ao da broca, de uma doença que acometeu os canaviais: "o mosaico da cana". José Vizioli, agrônomo da Escola Agrícola de Piracicaba, foi o responsável pelos estudos sobre essa doença (Oliver, 2001, p. 52-3), indicando até mesmo medidas para evitar que outros agentes fossem introduzidos no Brasil. De acordo com Vizioli, o Instituto Biológico, de "duvidosa utilidade" (O Estado de S. Paulo, 18.3.1925), não estava à altura das prerrogativas que lhe cabiam, "com resultados contraproducentes na prática, pois, uma a uma, as pragas e as moléstias mais graves das plantas econômicas começaram desde então a aparecer no país" (ibidem).

\section{A ação do governo e a resposta da ciência: Arthur Neiva, Costa Lima e a entomologia brasileira}

No primeiro dia de junho de 1924 chegavam a São Paulo, a convite da Secretaria de Agricultura, Arthur Neiva e Costa Lima, para fazer a identificação do inseto, estudar sua biologia e preconizar medidas para debelá-lo. Dirigiram-se a Campinas para coletar amostras do parasita e classificá-lo. No universo controlado do laboratório científico, longe do "mundo desorganizado" da fazenda de café (Latour, 1995), Neiva e Costa Lima produziram conhecimentos sobre o inseto, a começar pela identidade inferida a partir das características de seu próprio corpo, tornado visível por lupas e microscópios.

Para enfrentar-se a praga, foi mobilizada a entomologia, ciência à qual estavam ligadas as trajetórias de Neiva e Costa Lima. Médicos de formação, ambos começaram suas carreiras no Serviço de Profilaxia da Febre Amarela chefiado por Oswaldo Cruz, onde travaram contato com os insetos envolvidos na transmissão dessa doença. Incorporado ao Instituto Soroterápico de Manguinhos em 1906 (Instituto Oswaldo Cruz a partir de 1908), Neiva dedicou a maior parte de sua produção científica aos vetores de patologias humanas, principalmente a malária e a tripanossomíase descrita por Carlos Chagas - a Doença de Chagas (Borgmeier, 1940; Benchimol \& Sá, 2006). Os estudos de especialização de Neiva, feitos nos Estados Unidos e na Europa, foram direcionados para a entomologia médica, isto é, para os estudos de insetos que serviam ou podiam servir de hospedeiros intermediários e vetores a parasitos e microrganismos patogênicos, disciplina posta em evidência pela chamada "medicina tropical", no final do século XIX.

Quando convocado para estudar a praga dos cafeeiros, Neiva dirigia já por um ano o Museu Nacional, instituição que abrigava importantes coleções entomológicas e que acolhera a primeira 
${ }^{1}$ A entomologia econômica teve grande impulso nos Estados Unidos, onde contou com especialistas alocados no departamento federal de agricultura e nas estações experimentais estaduais. $\mathrm{O}$ adjetivo 'econômico' foi vulgarizado pelos norte-americanos, que enfatizaram o caráter pragmático do estudo de insetos diretamente envolvidos em prejuízos na lavoura. L. O. Howard, por muitos anos entomologista do departamento de agricultura daquele país, concorreu para a utilização corrente do termo, dadas as relações por ele estabelecidas com entomologistas de várias partes do mundo. repartição oficial dedicada especificamente à entomologia qualificada de 'econômica': o Laboratório de Entomologia Agrícola, fundado em 1910. Assim como a entomologia médica, a agrícola ou econômica conferia importância ao estudo dos insetos; neste caso, aqueles envolvidos no ataque às lavouras. ${ }^{1}$

Entrando no Serviço de Profilaxia da Febre Amarela em 1906, Costa Lima acompanhou Oswaldo Cruz na comissão de combate à febre amarela no Pará logo que completou sua formação médica. Como inspetor sanitário, Costa Lima chefiou as campanhas contra a febre amarela nas cidades de Santarém Novo e Óbidos, onde iniciou suas investigações sobre a biologia de insetos. A especialização da trajetória de Costa Lima na entomologia deveu-se à indicação de Oswaldo Cruz, que vira nele inclinação especial para aquele ramo das ciências. Desde 1914, embora continuasse a manter vínculos com o Instituto de Manguinhos, Costa Lima era professor de entomologia agrícola na Escola Superior de Agricultura e Medicina Veterinária (Bloch, 1968). Sua vasta produção científica, sobre diversas famílias de insetos, mostra o quanto os domínios médico e agrícola estavam imbricados, embora gradativamente ganhassem lócus institucionais próprios. Costa Lima dedicou-se ao estudo de uma das mais importantes pragas da cultura algodoeira: a lagarta rosada. Entre 1918 e 1920, chefiou o Serviço de Combate à praga, percorrendo vários estados do Nordeste. No ano seguinte, foi nomeado chefe do Serviço de Vigilância Sanitária Vegetal do Instituto Biológico de Defesa Agrícola e Animal.

A rede da pesquisa entomológica no Brasil, antes de corporificarse em espaços institucionais próprios, deveu-se a personagens que compuseram núcleos de estudos e "formaram escola". Alguns elementos nodais dessa rede concorreram para que a ciência dos insetos ganhasse espaço no Brasil, ao promover estudos importantes e arregimentar discípulos. Além de Neiva e Costa Lima, vale citar Adolpho Lutz, Emílio Goeldi e outros personagens alocados em instituições de pesquisa agrícola ou museus de história natural como Carlos Moreira, Adolpho Hempel e Gregório Bondar.

Além de ser notável entomologista, outro fator concorreu para a convocação de Neiva pelo governo paulista: sua relação prévia com as oligarquias cafeeiras estabelecida desde 1917, quando foi nomeado chefe do Serviço Sanitário no governo Altino Arantes (1916-1920) (Borgmeier, 1940). Neiva implementou então o Código Sanitário Rural, coroamento de delicadas negociações políticas com lavradores e seus representantes políticos. Estes resistiam à intervenção estatal em suas propriedades, e, até a gestão de Neiva, constituíram obstáculo quase intransponível à concretização dos serviços de saúde em áreas rurais (Castro Santos, 1987). A relevância dessa iniciativa para o episódio da broca repousa no fato de haver o cientista logrado estabelecer um canal de comunicação importante 
com a mesma oligarquia cafeeira que seria sua interlocutora por ocasião da praga. A concretização do serviço sanitário nas áreas rurais certamente concorreu para que delegassem a Neiva outro serviço que necessitaria de estratagema persuasivo igualmente complexo, quando a lógica de intervenção estatal nas propriedades novamente entrou em jogo em 1924.

A boa acolhida entre os paulistas da nomeação de Neiva como responsável pelos estudos sobre a praga assentava-se não somente em suas ações anteriores no estado, como também no fato de pertencer ao rol dos 'discípulos de Oswaldo Cruz', condição que dava grande legitimidade a um 'homem de ciência'. A morte de Oswaldo Cruz em 1917 desencadeara uma construção mitológica relacionada pragmaticamente a interesses políticos de segmentos da classe médica envolvidos com o movimento sanitarista. Os 'discípulos' eram encarados como herdeiros do patrimônio científico do mestre, elevado à condição de "pai da ciência experimental brasileira" (Britto, 1995).

A identificação taxonômica do inseto responsável pela broca-docafé feita por Neiva e Costa Lima em 1924 confirmou as suspeitas e acentuou a apreensão dos lavradores: tratava-se do Stephanoderes hampei (Figuras 1, 2 e 3), o mesmo agente que anos antes causara grande devastação nos cafeeiros de Java e Sumatra, a ponto de a cafeicultura precisar ser substituída pela cultura da borracha em muitas regiões. A identificação foi confirmada por entomologistas de instituições importantes da Europa, como o Instituto Agronômico de Paris e o Museu Britânico (Neiva, 1928, p. 21).

\section{A experiência de Java e o 'profeta' Edmundo Navarro de Andrade}

Confirmadas as suspeitas de que era a mesma praga do sudeste asiático, e conhecido seu potencial de devastação, entrou em cena Edmundo Navarro de Andrade, agrônomo e silvicultor que se notabilizara pelo programa de reflorestamento que implementara quando esteve à frente do Serviço Florestal da Companhia Paulista de Estradas de Ferro. Foi um dos arautos da disseminação do eucalipto no Brasil, tornando-se uma das maiores autoridades mundiais no assunto (Martini, 2004). Em 1919, após uma excursão a várias regiões do mundo, inclusive Java, na Indonésia, Navarro de Andrade publicara relatório no qual alertava para o perigo da possível introdução da broca no Brasil (O Estado de S. Paulo, 16.3.1919). Concretizada sua predição cinco anos depois, Navarro publicou matérias em $O$ Estado de S. Paulo, nas quais discorria sobre a praga em Java, num discurso alarmista e ao mesmo tempo entusiasta do governo de Carlos de Campos: 


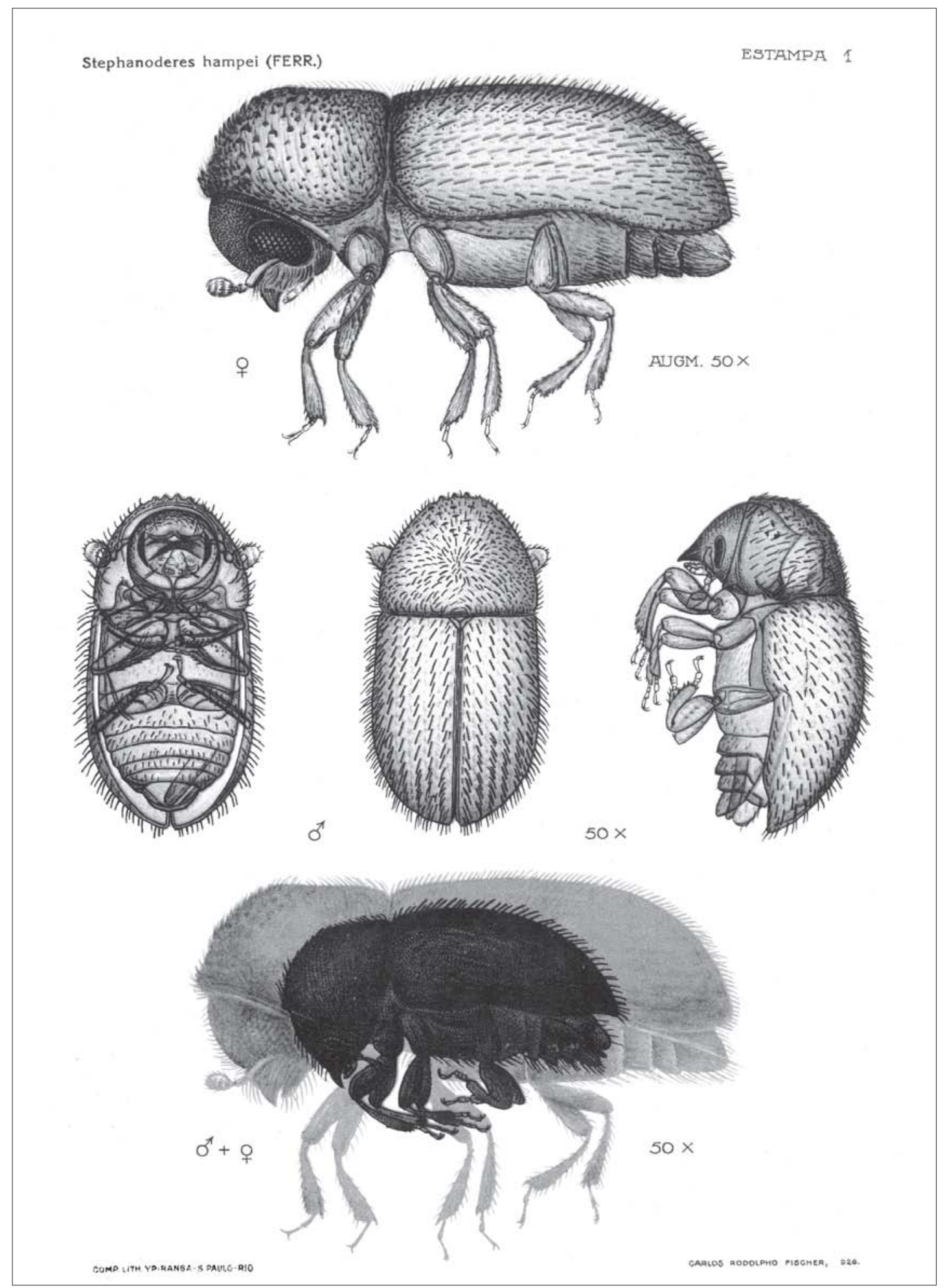

Figura 1 - O Stephanoderes, agente da broca do café, em ilustração de Carlos Rudolph Fischer. (Oliveira Filho, 1927). (Todas as fotos são do Arquivo Biológico). 


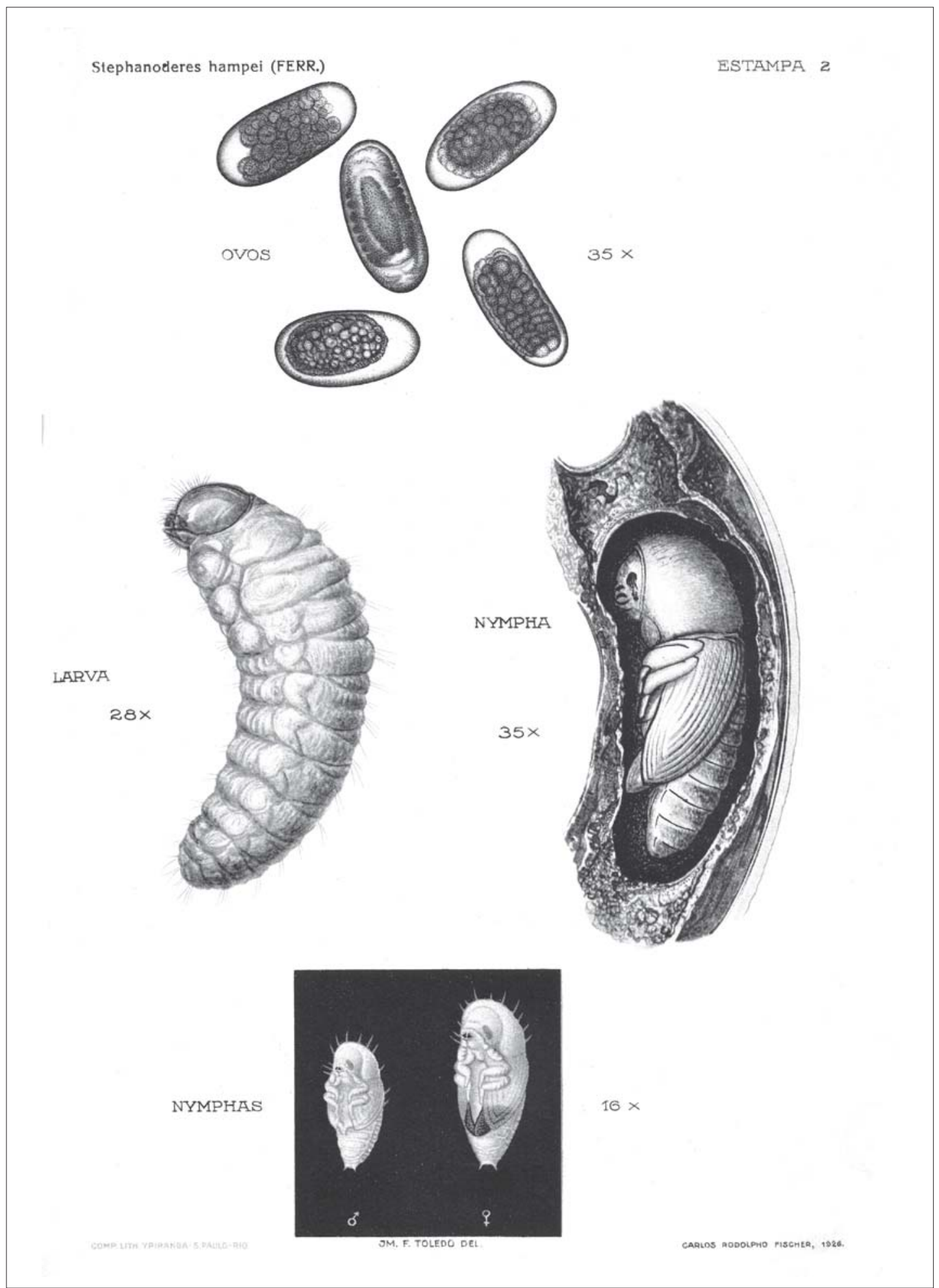

Figura 2 - Ovos, larvas e ninfas do Stephanoderes, em desenho de Fischer (Oliveira Filho, 1927). 
A nós a situação afigura-se gravíssima e formidável o perigo que nos ameaça. Felizmente, temos homens ao leme e todos os remadores estão prontos a obedecer à voz de comando ... Vão-se os anéis, mas salvem-se os dedos. (O Estado de S. Paulo, 01.6.1924)

Foi por volta de 1909 que a broca apareceu na parte ocidental da ilha de Java. A pequena extensão dos cafezais acometida na região levou os proprietários a optarem por eliminar completamente as plantações, através da poda total dos pés. Alguns anos depois, a praga reapareceu. Acreditou-se inicialmente que só atacava cafezais depauperados ou em anos de grandes chuvas. Lentamente a praga se propagou às culturas do centro e, em 1919, alcançou a parte oriental da ilha, algo que ninguém acreditava ser possível em razão da descontinuidade entre as regiões do leste e oeste, separadas por uma faixa de cinqüenta quilômetros ocupados com culturas refratárias ao Stephanoderes. Isso foi apontado como desvantagem de São Paulo

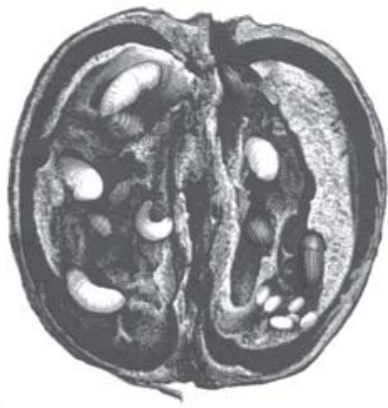

Figura 3 - llustração do interior de um grão de café atacado pela broca, feita por Carlos Rudolph Fischer (Neiva, Andrade \& Telles, 1924). em relação a Java, pois na zona produtora paulista a área dedicada à cafeicultura formava gigantesco e contínuo 'oceano verde'. Navarro de Andrade indicou outra vantagem de Java: a organização científica, que incluía o Instituto de Fitopatologia de Buitenzorg e estações experimentais especializadas de acordo com a cultura praticada em cada região (Howard, 1930, p. 354-7).

Embora os holandeses que colonizaram Java investissem em pesquisa, coube ao setor privado a iniciativa de promover os estudos de entomologia econômica, em precedência ao governo (ibidem, p. 359). Os fazendeiros criaram corporações para a defesa das respectivas culturas, e foram as estações agronômicas e laboratórios agrícolas mantidos por essas organizações privadas que levaram a cabo as campanhas contra as pragas agrícolas (O Estado de S. Paulo, 19.6.1924). Em relação à broca-do-café, os fazendeiros convocaram Karl Friederichs, entomologista alemão, para capitanear a campanha. Em 1922, quando os prejuízos tornaram-se agudos, os fazendeiros criaram um fundo pecuniário para a campanha, administrado pela Fundação da Broca da Cereja do Café (Koffiebessenboeboeck Fonds), inteiramente mantida com capital privado.

Num contexto completamente distinto, São Paulo adotou linha muito diferente de ação. Os fazendeiros, que mantinham vínculos de dependência estatal, ao mesmo tempo em que dominavam seus centros decisórios, esperaram que emanassem do Estado todas as iniciativas de combate à praga. E foi do governo paulista que parti- 
ram as ações da campanha em todos os níveis. Num primeiro momento, quando ainda eram desconhecidas a área infestada e a biologia do parasita, o secretário de Agricultura determinou medidas genéricas, como a proibição do embarque, nos trens, do café produzido em Campinas e áreas circunvizinhas. Esperava-se isolar a área acometida, de modo a evitar a contaminação de regiões e lotes de café indenes. Numerosos lotes e mesmo mercadorias que nenhuma relação tinham com o produto ficaram retidos. Diretamente feridos em seus interesses, lavradores e comerciantes atacaram violentamente a ação do governo. Mais uma vez os jornais locais constituíram o canal de expressão do descontentamento das oligarquias regionais. O Diário do Povo (03.6.1924) taxou a medida de "inqualificável ato de prepotência governativa", "ato ditatorial" e "campanha leviana de descrédito contra Campinas".

O perfil de intervenção do governo e da reação de Campinas guarda semelhanças com o perfil das ações e reações produzidas em tempos de epidemia. Para conter o alastramento da febre amarela na hinterlândia paulista durante a década de 1890 operou-se o controle do fluxo nas ferrovias, meio mais utilizado no transporte de pessoas e objetos (Telarolli Jr., 1996a). E quando o cólera grassou no Vale do Paraíba, em 1894-1895, houve grande descontentamento com a retenção de mercadorias nos armazéns da estrada de ferro Central do Brasil. Boa parte dos protestos aflorou nos jornais locais, acusando-se o governo de conspirar contra o comércio e os fazendeiros (Benchimol, 1999, p. 251).

Na década de 1920, esperou-se que a ciência e os cientistas respondessem com ações pontuais que não comprometessem o "formidável progresso e desenvolvimento de São Paulo" (O Estado de S. Paulo, 5.6.1924). Posicionaram-se diversos autores, procurando demonstrar conhecimento sobre o mal dos cafeeiros, o que acabou por resultar numa polifonia desencontrada de discursos. O já referido agrônomo José Vizioli dizia que em Java usava-se uma técnica de deitar o café em água com sabão e cal; Carlos Moreira, diretor do Instituto Biológico do Ministério da Agricultura, recomendava a circunscrição da área infestada, com queima das plantas atacadas e tratamento daquelas sadias com arseniato de cálcio e chumbo. Mello Morais, professor da Escola Agrícola de Piracicaba, sugeria a aplicação do verde-paris, arseniato habitualmente usado na agricultura. O agrônomo Manoel Lopes de Oliveira Filho, que depois integraria a Comissão de Estudo e Debelação da Praga Cafeeira, afirmava que o combate ao inseto requeria rapidez na colheita; corte das saias do cafeeiro; espalhamento cuidadoso dos montes e cordões; manutenção do cafezal limpo e fermentação do café com cal (O Estado de $S$. Paulo, 18.6.1924). O desacreditado diretor do IAC, Arthaud Berthet, também indicou medidas para combater a praga (Diário do Povo, 04.6.1924). 
Tal como os técnicos em pesquisa agrícola, os lavradores procuraram demonstrar um saber sobre a praga dos cafeeiros. A sugestão que ganhou maior repercussão e adeptos foi a que indicava o isolamento da área infestada, com a destruição dos cafeeiros atacados pela poda ou queima das plantas, e posterior indenização dos proprietários pelas perdas sofridas. Acreditava-se que essa medida salvaria a cafeicultura da bancarrota. As três agremiações agrícolas de São Paulo endossaram a idéia. Em 22 de junho de 1924, em reunião realizada em Campinas com "representantes das mais velhas estirpes paulistas", discutiu-se a base das indenizações. O fazendeiro Antônio de Castro Prado sugeriu a expropriação das fazendas pelo governo, com posterior reaquisição pelo antigo proprietário, quando já estivesse indene, pela metade do preço. Caso o proprietário julgasse cabíveis as medidas de combate, entregaria a propriedade ao governo para que a praga fosse debelada; caso contrário, ele próprio daria fim a seus cafezais através do fogo ou da poda (O Estado de S. Paulo, 24.6.1924). Esse episódio evidencia a relação 'privativa' que a elite cafeeira mantinha com o aparelho estatal, e guarda semelhanças com a postura adotada pelos mesmos cafeicultores quando da elaboração de políticas econômicas em prol da lavoura cafeeira. Celso Furtado (1968, p. 174) denomina "socialização das perdas" o mecanismo acionado pelos cafeicultores em momento de baixa do preço do café no mercado internacional. Para minimizar seus prejuízos, manipulavam a taxa cambial, desvalorizando a moeda nacional e transferindo o ônus para o setor importador e, conseqüentemente, para todos os que consumiam mercadorias importadas.

Quando começou a ganhar alento entre os fazendeiros a corrente que sugeria a destruição da safra, Neiva ameaçou abandonar a campanha contra a praga. Ele qualificou a idéia como "absurda"; como "método empírico e aberrante das normas científicas". Os que falavam em nome da ciência lograram subjugar os discursos discordantes, fator crucial para que levassem a cabo sua ação interventora sobre a cafeicultura.

\section{Uma comissão de cientistas a serviço do café}

O governo paulista reuniu Neiva, Costa Lima e Navarro de Andrade para fazer os estudos sobre a praga e indicar os meios para combatê-la. Em 10 de junho de 1924 foi entregue ao secretário do Ministério da Agricultura, Gabriel Ribeiro dos Santos, o relatório deles com as observações sobre a biologia do inseto, a área acometida e as medidas de combate.

Três áreas eram delimitadas conforme o grau de infestação. Entre os oito municípios visitados (num total de 19 propriedades), estavam contaminados os de Campinas, Indaiatuba e Mogi Mirim. 
Segundo o relatório, estavam praguejados dois milhões de cafeeiros (Neiva, Costa Lima \& Andrade, 1924).

As medidas indicadas no relatório mantiveram-se praticamente inalteradas durante toda a campanha. Como o inseto não completava seu ciclo evolutivo fora do fruto do cafeeiro, recomendou-se a medida denominada 'repasse', a qual consistia na catação dos frutos remanescentes após a colheita, seguida da destruição pelo fogo ou seu enterramento em covas (Figura 4). Esse método derivava de medidas similares adotadas em Java, e que chegaram ao conhecimento de Neiva graças ao intercâmbio de informações com os cientistas de lá. O repasse tornou-se o elemento basilar da estratégia de campanha. A complexidade e o rigor desse processo levaram a que posteriormente os cientistas brasileiros sugerissem aos fazendeiros a organização de turmas especiais de repassadores que entrariam em ação enquanto transcorria a colheita. O relatório de Neiva, Costa Lima e Navarro de Andrade sugeria outras medidas: abolir a lavagem do café atacado ou suspeito; expurgar o café recém-colhido e evitar a armazenagem prolongada nas tulhas, construções onde se depositava o produto antes de beneficiado.

O relatório afirmava que a praga jamais seria extinta; na melhor das hipóteses, seriam mantidos níveis desprezíveis de infestação. O governo optou por compor uma comissão científica para levar à frente a campanha contra a broca e nomeou Neiva seu diretor. Navarro de Andrade fez parte da Comissão, mas Costa Lima não aceitou o convite em virtude de seus encargos profissionais no Rio de Janeiro. Foi substituído por Adalberto Queiroz Telles, diretor de agricultura e agrônomo de poderosa família da oligarquia cafeeira, que anos antes tivera intensa participação no debate sobre o ensino agrícola.

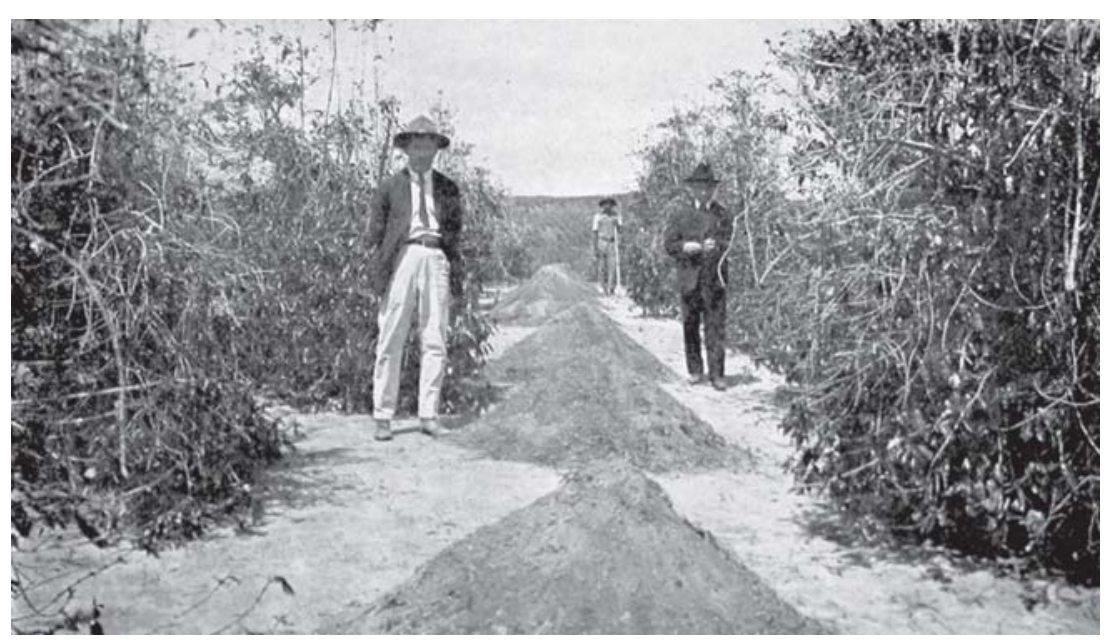

Figura 4 - Fotografia do repasse, com os técnicos da Comissão de Estudo e Debelação da Praga Cafeeira (Rodovalho, 1925). 
2 De acordo com Domingues (1995), os estudos sobre a praga dos canaviais ficaram a cargo do Imperial Instituto Fluminense de Agricultura. Uma primeira comissão foi composta por Felisberto Caldeira Brant Pontes, visconde de Barbacena, por Pedro Dias Gordilho Paes Leme, que veio a ser diretor do Instituto Fluminense, e por Miguel Antônio da Silva. A segunda comissão seria composta por Saldanha da Gama e Nicolau Moreira, e teria por fim complementar os estudos da primeira.
Juntamente com a comissão de técnicos, foi formada uma comissão de fazendeiros do grande capital cafeeiro, principalmente aqueles agremiados na Sociedade Rural Brasileira. Eram eles: Carlos Botelho, Bento de Abreu Sampaio Vidal, Carlos Leôncio de Magalhães, Otaviano Alves de Lima, Arthur Diederichsen, José Martiniano Rodrigues Alves e Júlio de Mesquita Filho (Neiva, 1928, p. 5-6).

As medidas previstas no relatório dos cientistas foram discutidas com os fazendeiros na já mencionada reunião realizada em Campinas em 22 de junho, episódio que mostra quão complexas (ou ainda acidentadas) eram as relações entre os primeiros e as lideranças do universo econômico cafeeiro. Um processo de negociação teria de ocorrer para que os enunciados científicos se adequassem aos interesses e exigências da cafeicultura, e vice-versa.

A opção pela comissão científica como resposta a uma praga da lavoura não era inédita. Em outros episódios dessa natureza foi adotada medida similar. Quando a lagarta atacou as folhas dos cafeeiros fluminenses no começo de 1860, o recém-criado Ministério da Agricultura reuniu numa comissão Frederico Leopoldo Cezar Burlamaqui, diretor do Museu Nacional; Francisco Gabriel da Rocha Freire e Ezequiel Correia dos Santos, respectivamente lentes de Botânica e Zoologia e de Química Orgânica da Faculdade de Medicina do Rio de Janeiro (Taunay, 1945). Não lograram resultados práticos, e os estudos foram entregues ao botânico Francisco Freire Allemão. Doutor em medicina e professor de botânica e zoologia da Faculdade de Medicina do Rio de Janeiro e da Escola Central, Allemão participara, em 1858, da Comissão Científica de Exploração. Realizando estudos sobre as riquezas naturais do interior do país, a Comissão contou com a presença de Freire até 1861 (Domingues, 1995). Contemporânea à praga dos cafezais fluminenses e à dos canaviais baianos, ele suscitou o mesmo perfil de resposta - a formação de uma comissão de técnicos para encetar os estudos² (Domingues, 1995, p. 230-41).

Em 1924, num contexto já bem diferente, quando o café figurava de modo absoluto nas exportações, uma comissão científica foi incumbida de solucionar o problema daquela que era, por muitos, considerada a pior praga dos cafeeiros.

Inicialmente, em quatro salas na praça da República, na capital paulista, foram acomodados o gabinete do chefe da Comissão, a seção de estatística e os laboratórios de química e entomologia. Tão logo foi instalada a Comissão, seus trabalhos foram interrompidos, em julho de 1924, pela revolta tenentista comandada por Isidoro Dias Lopes. O movimento durou 22 dias e desorganizou o cotidiano da capital paulista. Pretendia instaurar um governo revolucionário por meio de um golpe de Estado, promovido por setores do exército descontentes com a situação institucional e política. Embora os revoltosos somassem aproximadamente três mil pessoas, a revolta 
não foi bem-sucedida: as tropas legalistas logo tomaram São Paulo e os insurretos rumaram para o interior paulista e para os estados do Mato Grosso e Paraná, onde se juntaram aos rebeldes do Rio Grande do Sul, engrossando a Coluna Prestes que então se formava.

Os trabalhos da comissão chefiada por Neiva foram reiniciados em agosto de 1924, quando a colheita já se achava em seu período final. Os dois laboratórios referidos prosseguiram os estudos sobre a biologia do inseto e os agentes químicos para combatê-lo (Figura 5). O melhor produto a ser utilizado no expurgo deveria ser eficaz no extermínio do parasita e ainda preservar as qualidades comerciais do café. Por isso, os trabalhos foram feitos com a colaboração de degustadores e classificadores da Associação Comercial de Santos. Métodos como o expurgo com água quente ou pela fermentação natural do café, que consistiam, basicamente, em matar o parasita pelo calor, foram dispensados por comprometer as qualidades do café (Neiva, Andrade \& Telles, 1925a, p. 7).

O sulfureto de carbono, formicida habitualmente utilizado na lavoura, foi considerado o melhor agente para expurgo do Stephanoderes, levando seu preço às alturas. Diante disso, os cientistas propuseram ao governo a montagem de uma fábrica que produzisse o formicida. Ameaçadas pela possível concorrência estatal, as indústrias químicas Companhia de Óleos e Produtos Chimicos, Indústrias Reunidas F. Matarazzo e Sociedades de Produtos Chimicos Elekeiroz firmaram um acordo com a comissão, pelo qual o preço do sulfureto ficou estabilizado em quarenta mil réis (Figura 6). A qualidade do produto ficaria sob inspeção constante dos técnicos do laboratório de química.

A comissão recomendou a construção, nas próprias fazendas, de câmaras para expurgo do café, a fim de que fosse desinfetado logo após a colheita (Figura 7). O transporte dos grãos deveria ser feito em sacas, para que o expurgo fosse mais eficaz e se evitasse a disseminação do parasita pela propriedade. Não somente o café colhido, mas também a sacaria usada em seu acondicionamento e transporte ficou sujeita ao expurgo. Para não atravancar o fluxo da produção e comércio cafeeiros, o governo paulista, por indicação dos cientistas, construiu câmaras para expurgo da sacaria em pontos estratégicos do estado (Figura 8). Em Santos foram instaladas quatro autoclaves, com capacidade para cerca de 2.200 sacos vazios (Figura 9). As sacas só poderiam transitar pelas ferrovias acompanhadas de uma guia, assinada e carimbada pelo chefe de expurgo local.

A palha resultante do beneficiamento do café e habitualmente utilizada como fertilizante também passou a ter de ser expurgada antes de seu reaproveitamento, para evitar a disseminação de detritos que contivessem o inseto (Neiva, Andrade \& Telles, 1925a, p.44). 

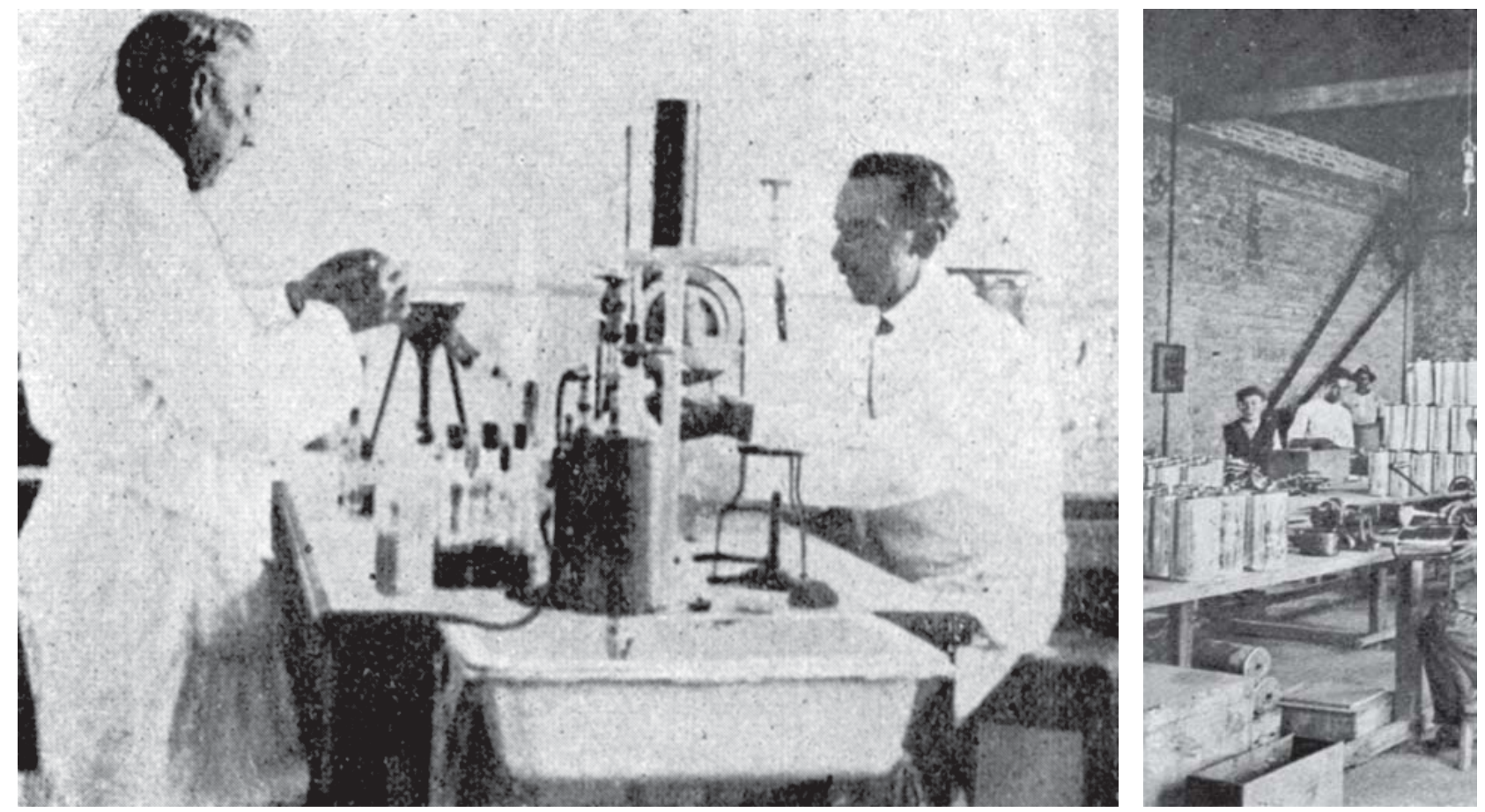

Figura 5 - Técnicos no laboratório de química fazendo análise do sulfureto de carbono e inspeção de amostras de café (Pamplona, 1927).
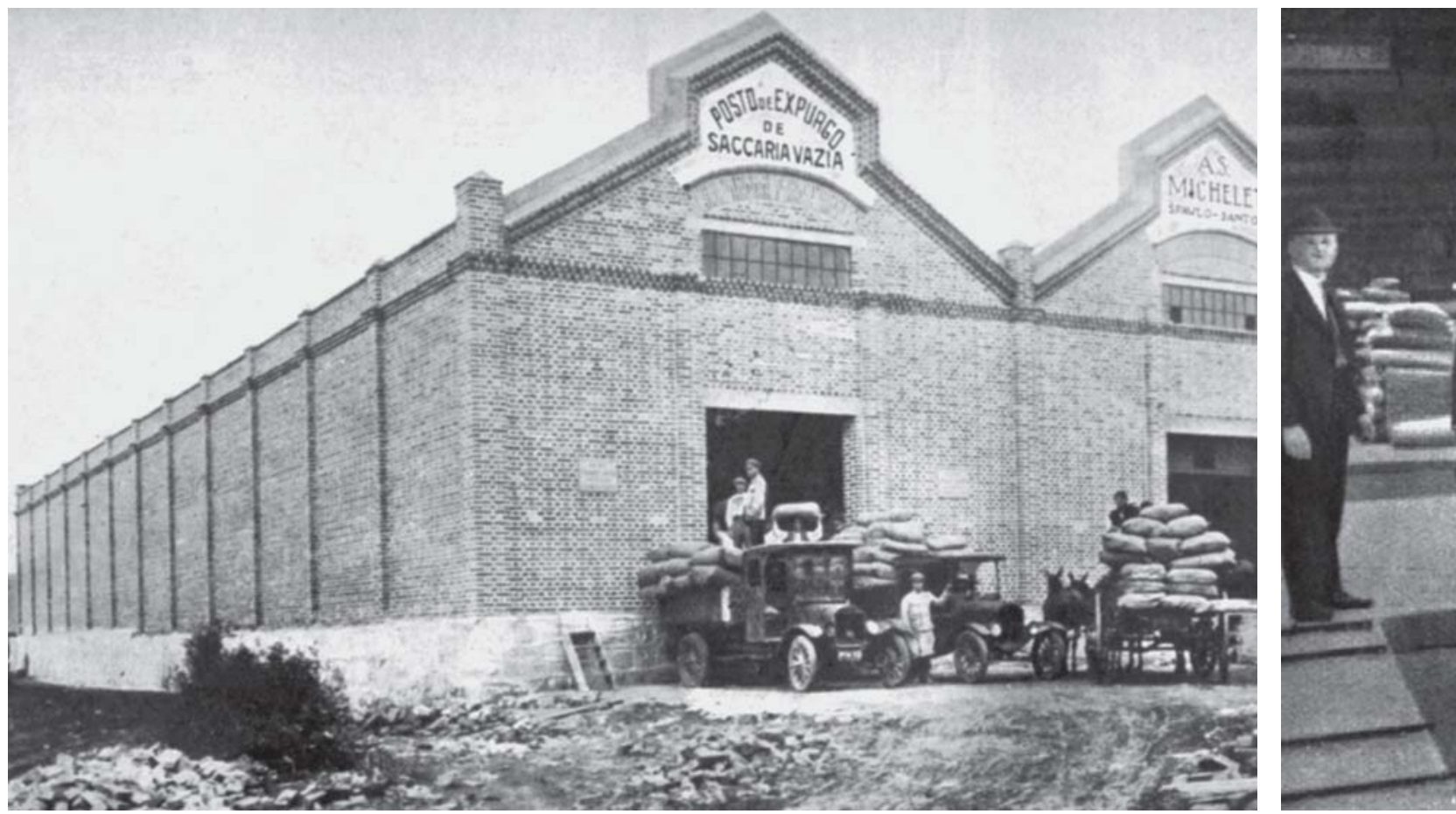

Figura 8 - Posto de expurgo da sacaria vazia em São Paulo (Hucke, 1925). 


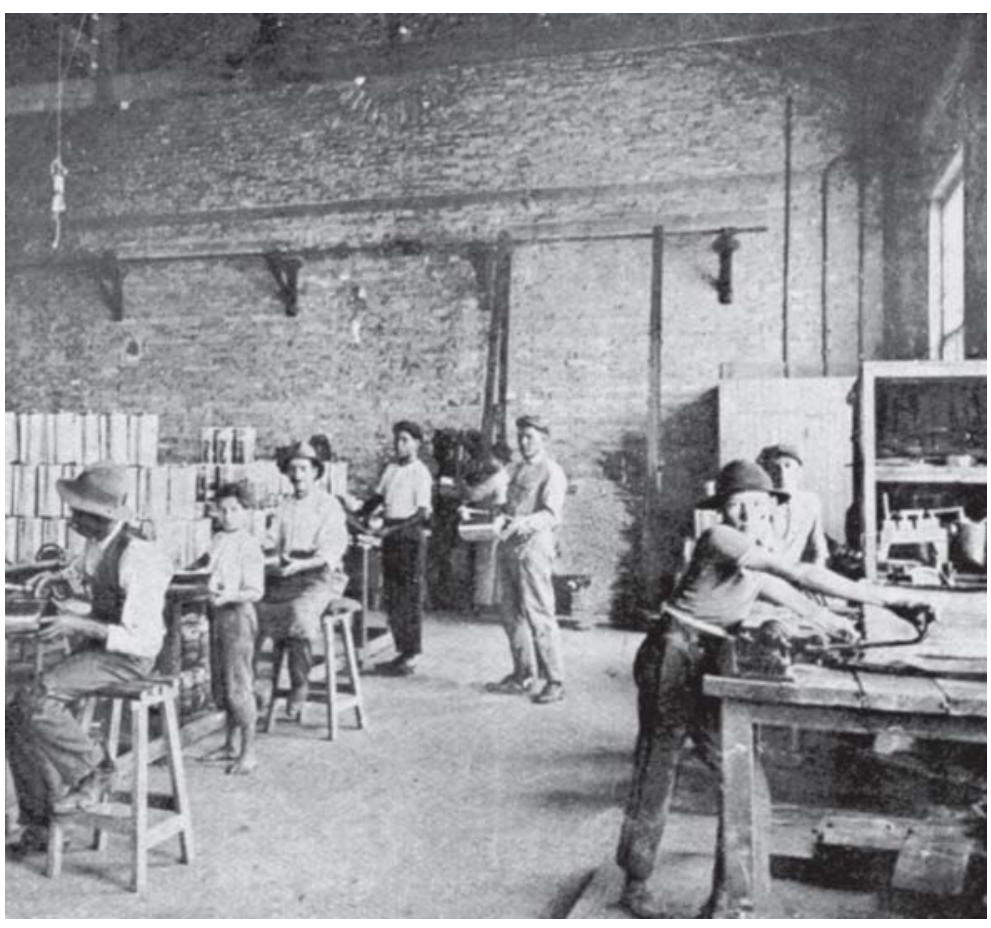

Figura 6 - Interior da fábrica de sulfureto de carbono Matarazzo, uma das que acordaram com a Comissão em produzir e comercializar o formicida a preços fixos (Hucke, 1925).

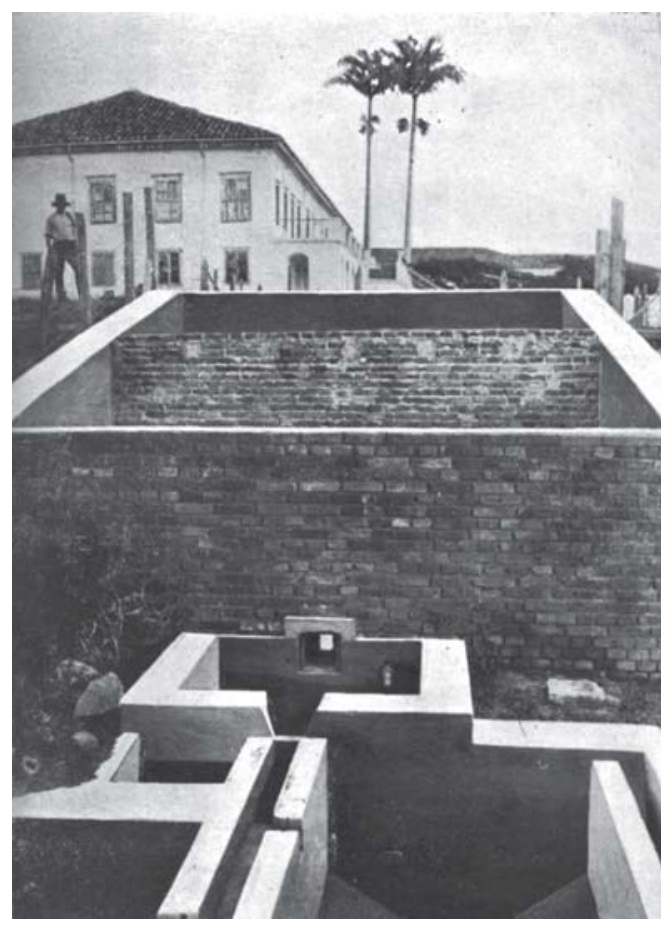

Figura 7 - Câmara de expurgo do café colhido em fazenda de Campinas.

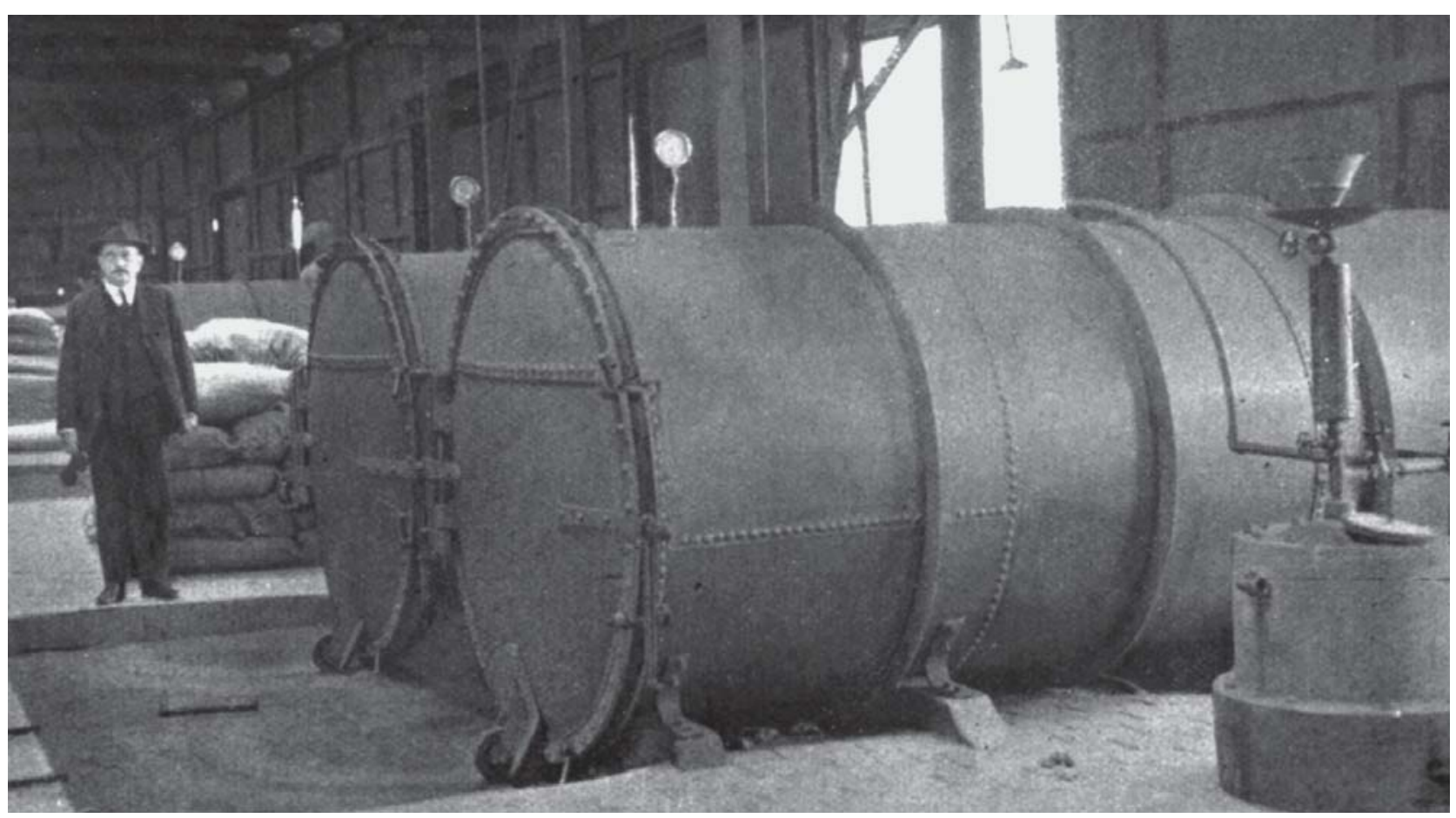

Figura 9 - Autoclaves para expurgo da sacaria vazia no porto de Santos (Neiva, Andrade \& Telles, 1925a). 
Durante o ano de 1924 a praga expandiu-se continuamente pelo território paulista. Em setembro desse ano falava-se em 25 municípios contaminados, número aumentado uma semana depois para 28 (Figura 10). Em outubro, eram apontados 36 municípios acometidos pela broca (ibidem, p. 9-26). Isso contrariou as expectativas daqueles que esperavam a debelação do mal em curto período. Juntamente com a praga, ampliavam-se as prerrogativas da Comissão, que iam além do estudo do Stephanoderes, e que passou a atender até mesmo consultas vindas de praticamente todas as regiões do país.

Em dezembro de 1924, foi apresentado à Câmara Estadual paulista projeto de lei que criava uma comissão permanente, a Comissão de Estudo e Debelação da Praga Cafeeira. Instituída em 26 daquele mês pela Lei 2.020, a qual foi regulamentada pelo presidente do estado Carlos de Campos por meio do Decreto 3.816, em janeiro de 1925 (Comissão de Estudo e Debelação da Praga Cafeeira, 1925). As prerrogativas permaneciam as mesmas: a Comissão cuidaria dos estudos sobre a praga e da aplicação de medidas contra ela. Seu organograma, porém, foi ampliado, incluindo, além do chefe do serviço, que continuou sendo Arthur Neiva, o inspetor fiscal, os inspetores regionais, os chefes de expediente e cargos meramente burocráticos: datilógrafos, arquivistas, auxiliares de escritório etc.

O laboratório de química foi entregue à direção de João Baptista da Rocha, professor da Escola de Farmácia de São Paulo, coadjuvado por um químico auxiliar, um técnico e um servente. Além de prosseguir a análise e inspeção do sulfureto oferecido no mercado, investigariam outros agentes eficazes na extinção do Stephanoderes. O laboratório de entomologia (Figura 11) ficou a cargo de Manoel Lopes de Oliveira Filho, secundado por dois entomologistas auxiliares, um fotógrafo e um servente. Esse laboratório continuou a fazer os estudos sobre a biologia do parasita e os exames de amostras de café atacado remetidas pelos lavradores. O chefe da Comissão era auxiliado por dois técnicos: Adalberto Queiroz Telles, responsável pelo setor do expurgo e experimentação de novos processos em fazendas, e Edmundo Navarro de Andrade, encarregado de superintender e fiscalizar as propriedades dos municípios contaminados. Havia ainda uma seção de estatística e um museu com amostras do Stephanoderes e de vários outros insetos prejudiciais à lavoura (Figura 12).

A Comissão teve de mudar do 'acanhado prédio' da praça da República para um espaço maior, na rua Florisbella, também na capital paulista (Figura 13). Em abril de 1925, foi inaugurada uma sucursal em Campinas, aproximando a Comissão dos lavradores da região mais seriamente acometida.

O aparato técnico instalado pela Comissão de Estudo e Debelação da Praga Cafeeira constituía por si só um recurso destinado a 


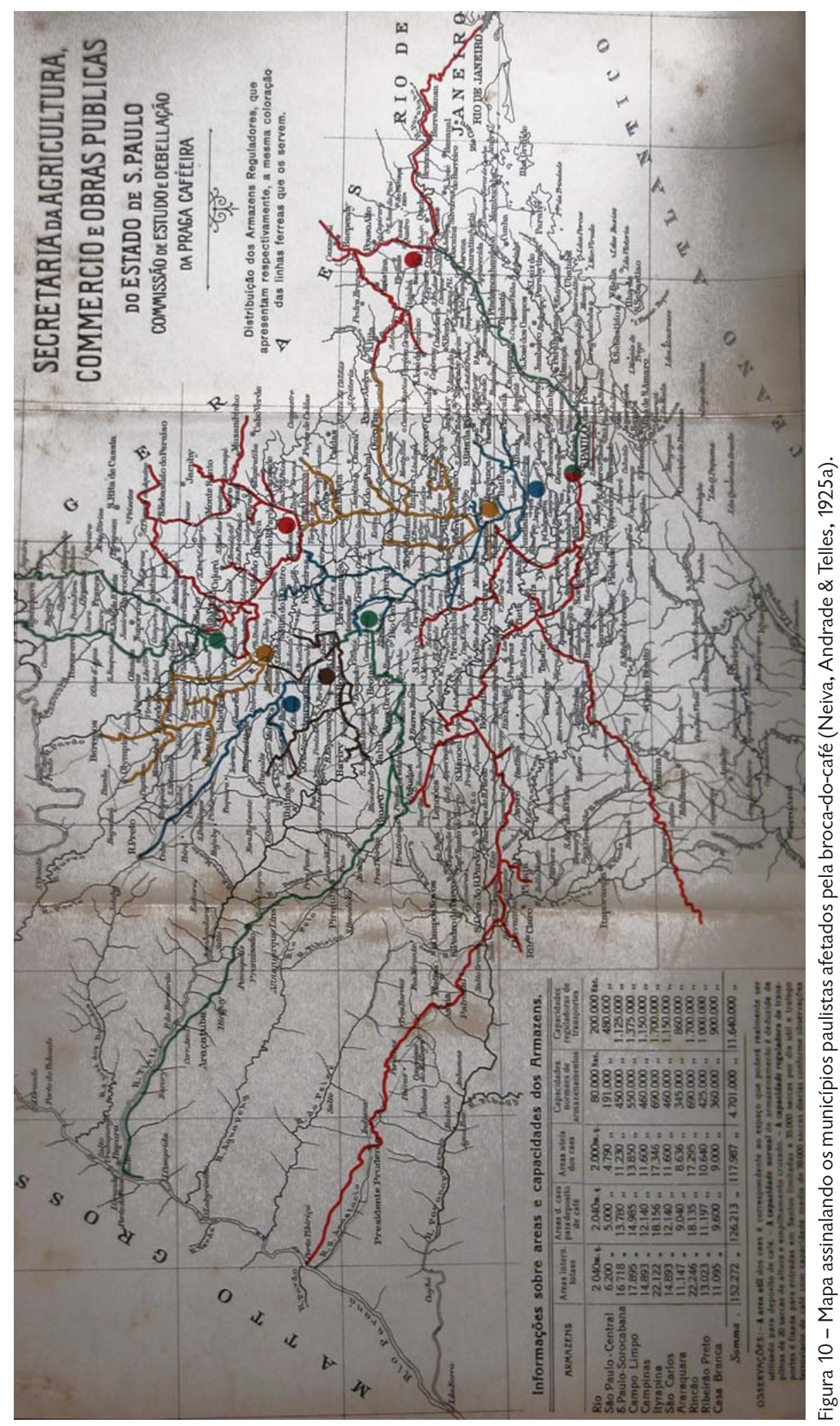


provocar nos lavradores a rendição às 'evidências' produzidas pela ciência. Esperava-se que o museu e os laboratórios, abertos à visitação pública, arrebatassem a imaginação dos leigos, perturbando até mesmo "os espíritos menos interessados nesses assuntos" (O Estado de S. Paulo, 3.1.1927).

\section{Coagir para combater: a cafeicultura sob vigilância}

Ao ser formada a comissão científica (refiro-me à sua primeira versão), o presidente da República delegara ao estado de São Paulo, através do Decreto 16.059, de 21 de junho de 1924, as medidas de defesa fitossanitária previstas no Decreto 15.198, de 21 de dezembro de 1921. Este regulamentava as medidas a tomar em casos de epifitias e as prerrogativas dos inspetores que atuariam nos locais atingidos: o exame de plantas, com o despacho do atestado de sanidade ou a proibição do trânsito e destruição daquelas praguejadas; a inspeção das propriedades e seu isolamento, quando contaminadas. Assim como os regulamentos de saúde pública instituídos a partir de meados do século XIX, o regulamento fitossanitário determinava a notificação compulsória pelos proprietários à autoridade pública de qualquer caso de praga ou doença vegetal em seus domínios.

Com a Lei 2.020, a própria Comissão de Estudo e Debelação da Praga Cafeeira foi investida do poder de polícia fitossanitária,

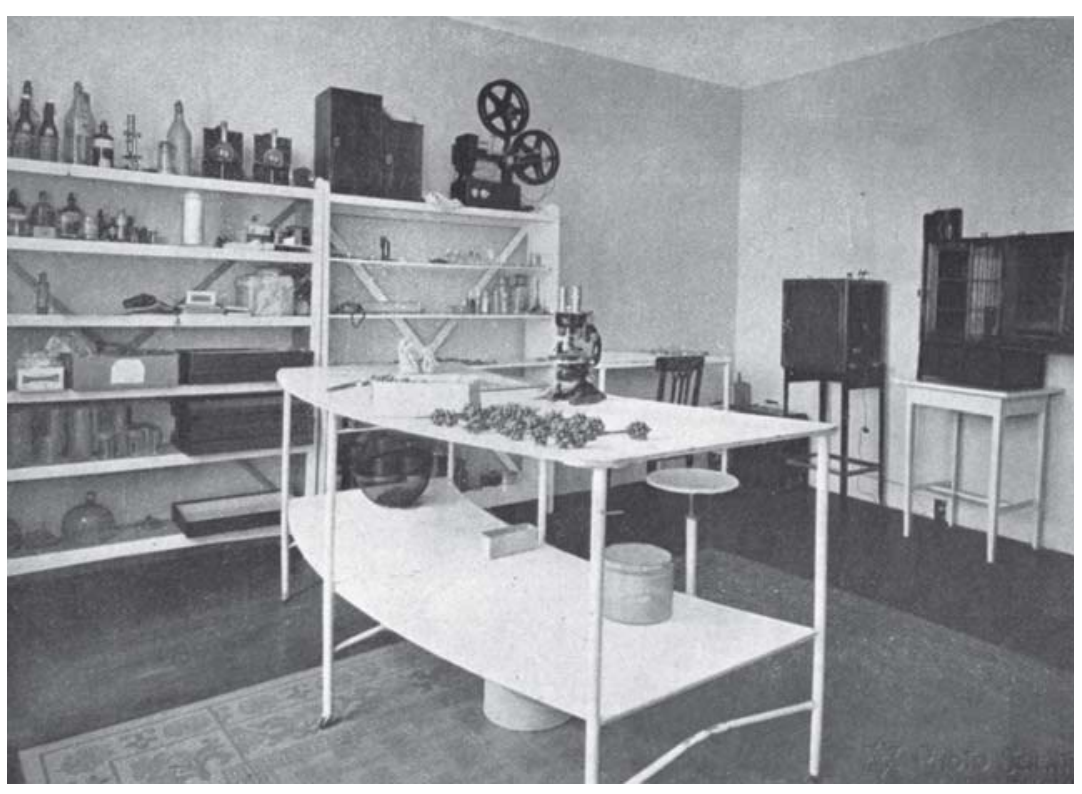

Figura 11 - Laboratório de entomologia da Comissão de Estudo e Debelação da Praga Cafeeira (Neiva, Andrade \& Telles, 1925b).

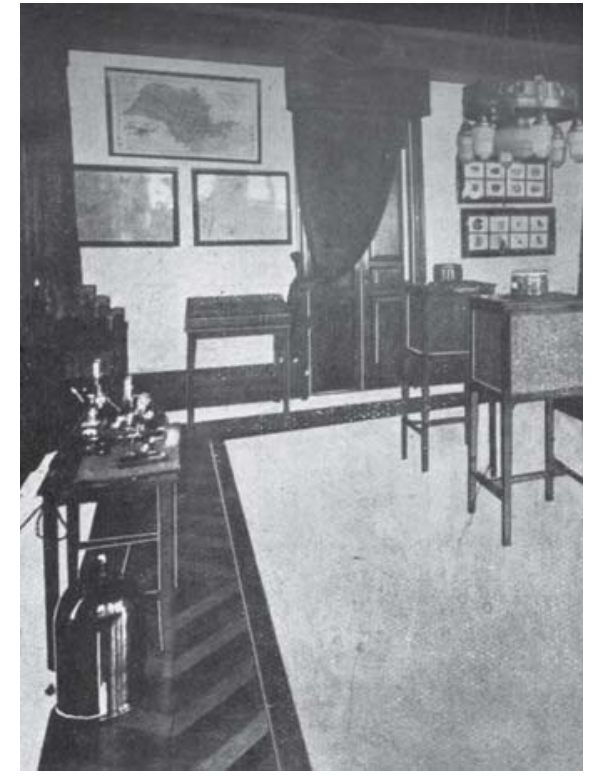

Figura 12 - Mostruário da Comissão de Estudo e Debelação da Praga Cafeeira, com cartazes instrutivos sobre a broca. (Neiva, Andrade \& Telles, 1925a). 
cabendo a ela a destruição de cafeeiros abandonados que julgasse suspeitos ou contaminados. A lei até mesmo reiterava a notificação compulsória às autoridades do aparecimento da praga em qualquer propriedade. Os infratores ficavam sujeitos a multas entre cinqüenta e cinco mil réis (Comissão de Estudo e Debelação da Praga Cafeeira, 1925).

Complexo aparato foi montado para fiscalizar as zonas cafeeiras e averiguar o cumprimento das medidas preconizadas. A área infestada foi dividida em vinte zonas, cada qual subordinada a um inspetor regional, responsável por percorrer as fazendas, anotar o grau de infestação dos cafezais e prescrever as medidas de combate. Quando detectava a praga, o fiscal instruía o lavrador sobre como proceder no período da colheita e fiscalizava o expurgo antes e depois do fechamento das câmaras. O repasse também era fiscalizado pelo inspetor regional, que instruía o lavrador, caso a medida fosse incorretamente executada (Neiva, 1928, p. 18). O município de Campinas foi dividido em nove zonas, cada uma a cargo de um inspetor, cabendo a ele a fiscalização de uma média de 2,7 milhões de cafeeiros (ibidem, p. 17). Os inspetores preparavam relatórios sema-nais, dando conta de cada propriedade visitada: nome do proprietário, número de cafeeiros, grau de infestação observado e condições em que se praticava o expurgo e o repasse. Em certa altura, os próprios colonos, suspeitos de concorrerem para a disseminação da praga quando mu-
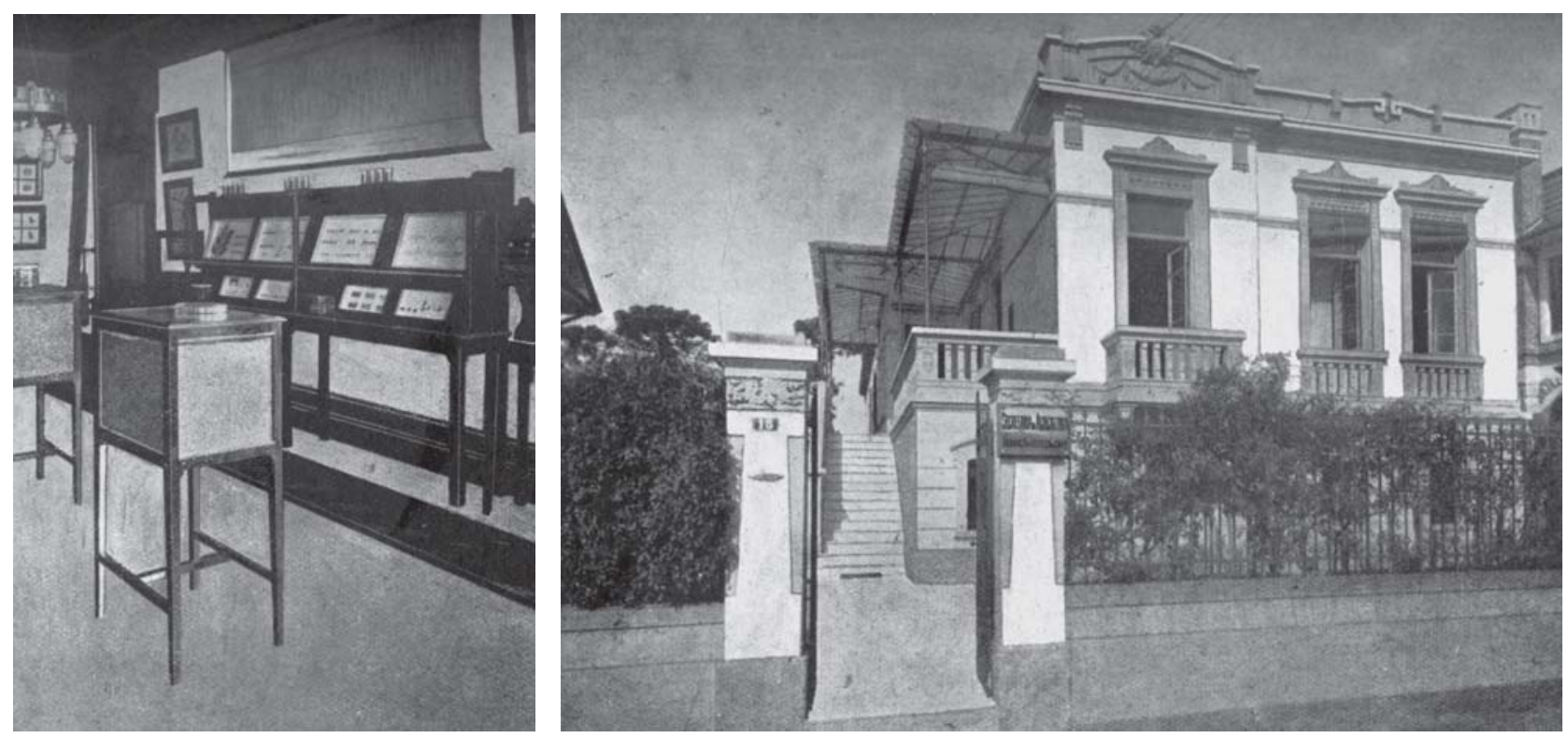

Figura 13 - Prédio-sede da Comissão de Estudo e Debelação da Praga Cafeeira, localizado à Rua Florisbella, na capital paulista. (Neiva, Andrade \& Telles, 1925b). 
davam de propriedade, foram submetidos à inspeção de suas roupas, bagagens e ferramentas (Figura 14).

Esses inspetores regionais eram supervisionados por um inspetor fiscal diretamente subordinado ao auxiliar técnico da Comissão. Além de ser o responsável pelo município de Campinas, o inspetor fiscal atestava a exatidão dos relatórios e fichas apresentados pelos inspetores regionais, e geria as câmaras de expurgo de sacaria, controlando sua receita e funcionamento. Observam-se muitas semelhanças com o sistema verticalizado de controle que a Fundação Rockefeller adotava na campanha contra a febre amarela e que Fred Soper levaria aos extremos no rigor e na eficiência após 1930 (Benchimol, 2001; Lowy, 1994).

Os municípios tiveram liberdade para promulgar leis próprias de combate à praga, e diversas câmaras assim o fizeram, como as de Campinas, Piracicaba e Sertãozinho. Campinas organizou um serviço de fiscalização do expurgo, medida que se tornou obrigatória a partir da Lei 331, de 23 de junho de 1924, promulgada pelo prefeito municipal Miguel de Barros Penteado (Gazeta de Campinas, 24.6.1924).

A vigilância exercida pela Comissão obedecia a uma ordenação hierárquica que culminava no chefe do serviço, Arthur Neiva. Segundo O Estado de S. Paulo (03.1.1927) o sistema de arquivamento das informações compunha "uma síntese admirável da vida rural de São Paulo, nos seus mínimos detalhes, na sua clareza absoluta, na sua formidável estrutura organizadora". Por meio das fichas e relatórios, o mundo da cafeicultura foi traduzido para a Comissão, transformando-se os dados capturados pelos fiscais e técnicos em gráficos, tabelas e equações que conferiam estatuto de cientificidade ao discurso de Neiva e seus colaboradores.

Assim como ocorria na saúde pública desde Oswaldo Cruz, a luta contra a broca era vista como uma cruzada militar, aspecto

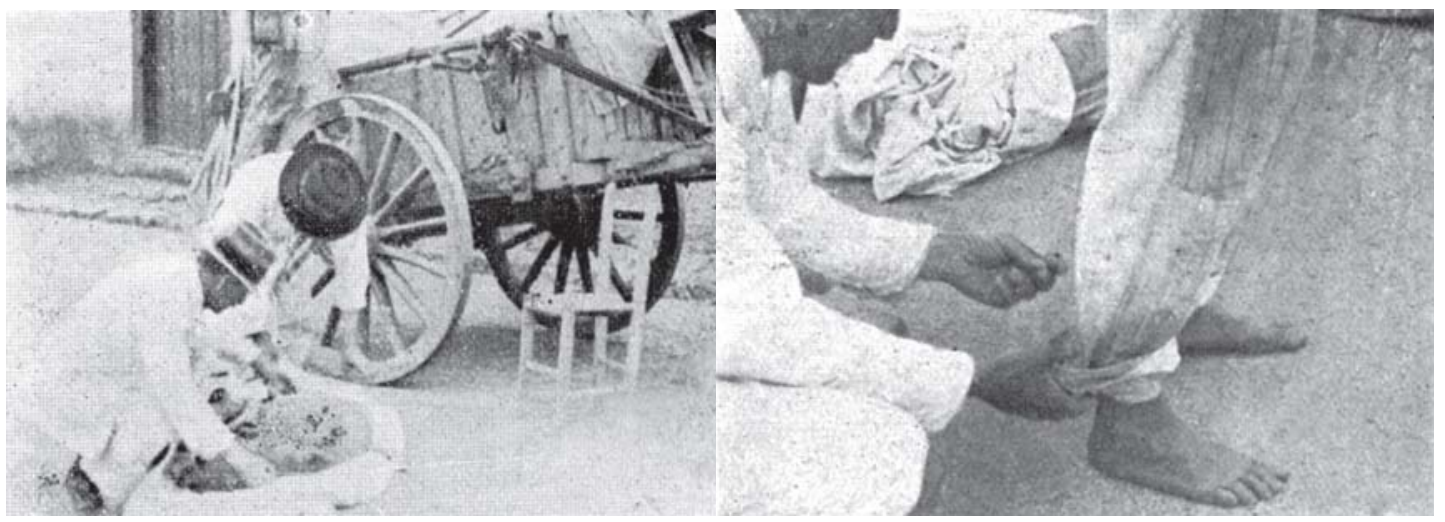

Figura 14 - Inspeção da bagagem de colonos em mudança, apontados como responsáveis pela disseminação da broca entre as propriedades (Pamplona, 1927). 
reforçado pelas constantes analogias com as estratégias de guerra. A eventual derrota da campanha contra a praga foi comparada "à ruína da Alemanha pela guerra" (Correio da Manhã, 12.6.1924), uma vez que o Brasil perderia "o maior padrão de glórias e realidades", conferido pelo café. Apelava-se para a consciência coletiva dos cidadãos que deveriam atuar com disciplina, "sem a qual não há guerra que se ganhe" (O Estado de S. Paulo, 21.6.1924). Cada paulista deveria "ser um soldado, e cada soldado, um espião" (ibidem, 22.6.1924).

Apesar das leis e da fiscalização, muitos tentaram burlar as medidas instituídas pela Comissão. Alguns procuravam transportar café e sacos vazios em automóveis nas estradas de rodagem, para fugir à rigorosa fiscalização nas estações ferroviárias. Outros enviavam sementes de café de áreas contaminadas para zonas indenes (Neiva, Andrade \& Telles, 1925b, p. 46). Houve o caso de um fazendeiro que, ao invés de executar o expurgo, punha latas vazias de sulfureto sobre a câmara quando o fiscal fazia sua inspeção. Segundo $A$ Broca do café, coluna que regularmente dava os informes sobre a praga na imprensa, "se procurava, por todos os modos inutilizar a campanha contra a broca ... não padecia dúvida que a broca encontrava no lavrador seu mais poderoso amparo". (O Estado de S. Paulo, 23.9.1924)

\section{Uma ampla campanha de divulgação científica}

Um dos desafios da Comissão era que as medidas determinadas para combate à praga e o conhecimento produzido chegassem a todos aqueles ligados à atividade cafeeira. Reconfigurado em linguagem inteligível, clara e concisa, o saber científico da Comissão precisava atingir o mundo das fazendas de café, com suas práticas rotineiras de produção. Número nada desprezível de pessoas procurava amenizar a gravidade da praga, afirmando que ela sempre existira. Esse artifício retórico, que desqualificava a ação interventora dos cientistas, tinha também a ver com a confusão entre o Stephanoderes, o responsável pela crise em curso, e o Araecerus fasciculatus, conhecido vulgarmente como "caruncho das tulhas", que não tinha o mesmo potencial de destruição do primeiro inseto (Oliveira Filho, 1927).

De acordo com os porta-vozes da Comissão, os "incrédulos" e "espíritos incultos e acanhados" representavam sério obstáculo para que os meios de combate fossem adotados na escala necessária. Num primeiro nível, a comunicação dos cientistas com a população leiga foi feita através de uma coluna na imprensa intitulada A Broca do café, veiculada pelos jornais O Estado de S. Paulo, Correio Paulistano, Jornal do Commercio e Fanfulla, este voltado para a comunidade italiana e redigido na língua nativa dos imigrantes. A periodicidade da coluna variou, mas ela foi regularmente publicada enquanto perdurou a comissão científica. A Broca do café tratava do 
andamento e das realizações da campanha, divulgando os municípios contaminados e as medidas que deveriam ser observadas. $\mathrm{O}$ repasse foi, de longe, o tema predominante. Enfatizava-se insistentemente sua eficácia no controle da praga, e procurava-se mostrar que era possível conciliar o processo com obtenção de lucros, contradizendo aqueles que alegavam falta de braços ou recursos para os esforços e as despesas adicionais exigidos pela operação. A estatística - "ciência por excelência dos porta-vozes e estadistas" (Latour, 2000, p. 386) - fortalecia o discurso da Comissão procurando constituir "prova irrevogável" de que somente por meio do repasse lograr-se-ia o controle da praga.

Uma série de vinte publicações da Comissão foi editada pela Secretaria de Agricultura paulista. A distribuição variava conforme a natureza das informações veiculadas - artigos técnicos ou material direcionado aos leigos. A primeira publicação da série consistiu no relatório de Arthur Neiva, Edmundo Navarro de Andrade e Costa Lima, entregue ao secretário de agricultura Gabriel Ribeiro dos Santos em junho de 1924. Era um folheto avulso que discriminava todas as medidas indicadas para o combate à praga.

A divulgação assumia caráter de propaganda ao incluir elementos chamativos destinados a persuadir os lavradores. O componente visual dominou a segunda publicação da série de folhetos da Comissão: um cartaz ricamente ilustrado com figuras coloridas feitas por Rudolph Fischer, desenhista alemão contratado por Oswaldo Cruz para fazer os trabalhos litográficos de Manguinhos. O desenho de um ramo de cafeeiro com frutos em diferentes graus de maturação, indicando os pontos onde era observada a broca, ensinava ao lavrador como reconhecer a praga em seu cafezal (Figura 15). A figura mostrava o parasita em sucessivos estágios de evolução e aspecto

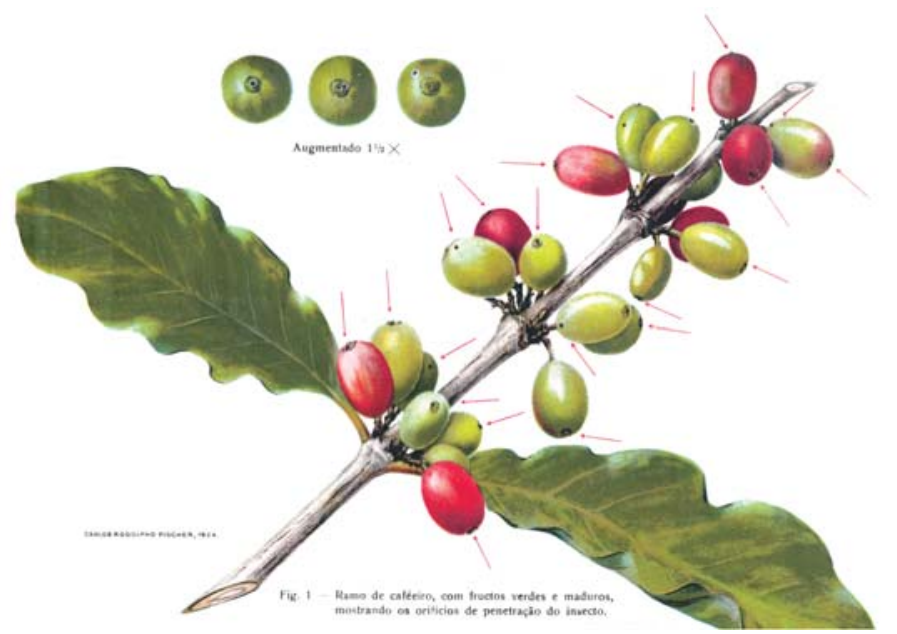

Figura 15 - Galho de cafeeiro ilustrado por Carlos Rudolph Fischer, onde se indicam os locais de penetração da broca (Neiva, Andrade \& Telles, 1924). 
dos estragos que causava no grão de café. As imagens eram acompanhadas de um texto que indicava, de forma didática, as características do Stephanoderes, seu ciclo de vida e os meios de combatê-lo (Neiva, Andrade \& Telles, 1924). A tiragem desse cartaz foi de trinta mil exemplares, afixados em locais públicos, principalmente nas estações ferroviárias, pontos de passagem obrigatórios para aqueles que lidavam com a cultura cafeeira no interior paulista. Seguiram-se ao cartaz publicações mais técnicas. A de número 4 tornava público o regulamento federal de defesa fitossanitária, que agora investia São Paulo da autoridade para levar a cabo as prerrogativas nele delineadas.

Além dos textos e imagens impressos, o serviço de divulgação providenciou a remessa de amostras de café atacado pelo Stephanoderes e exemplares do inseto a todas as Câmaras Municipais e prefeituras do estado de São Paulo. As amostras eram acompanhadas de cartaz alusivo às medidas de combate.

Do programa de divulgação da Comissão fez parte, também, a cartilha Histórias de um bichinho malvado (von Ihering, 1925) confeccionada para ser distribuída nas escolas rurais de São Paulo (Figura 16). A estratégia perspicaz consistia em atingir indiretamente os pequenos sitiantes, em sua maioria analfabetos, por meio de seus filhos, que em geral os ajudavam na colheita. As medidas a tomar para combater o Stephanoderes seriam assim pedagogicamente inculcadas nas crianças.

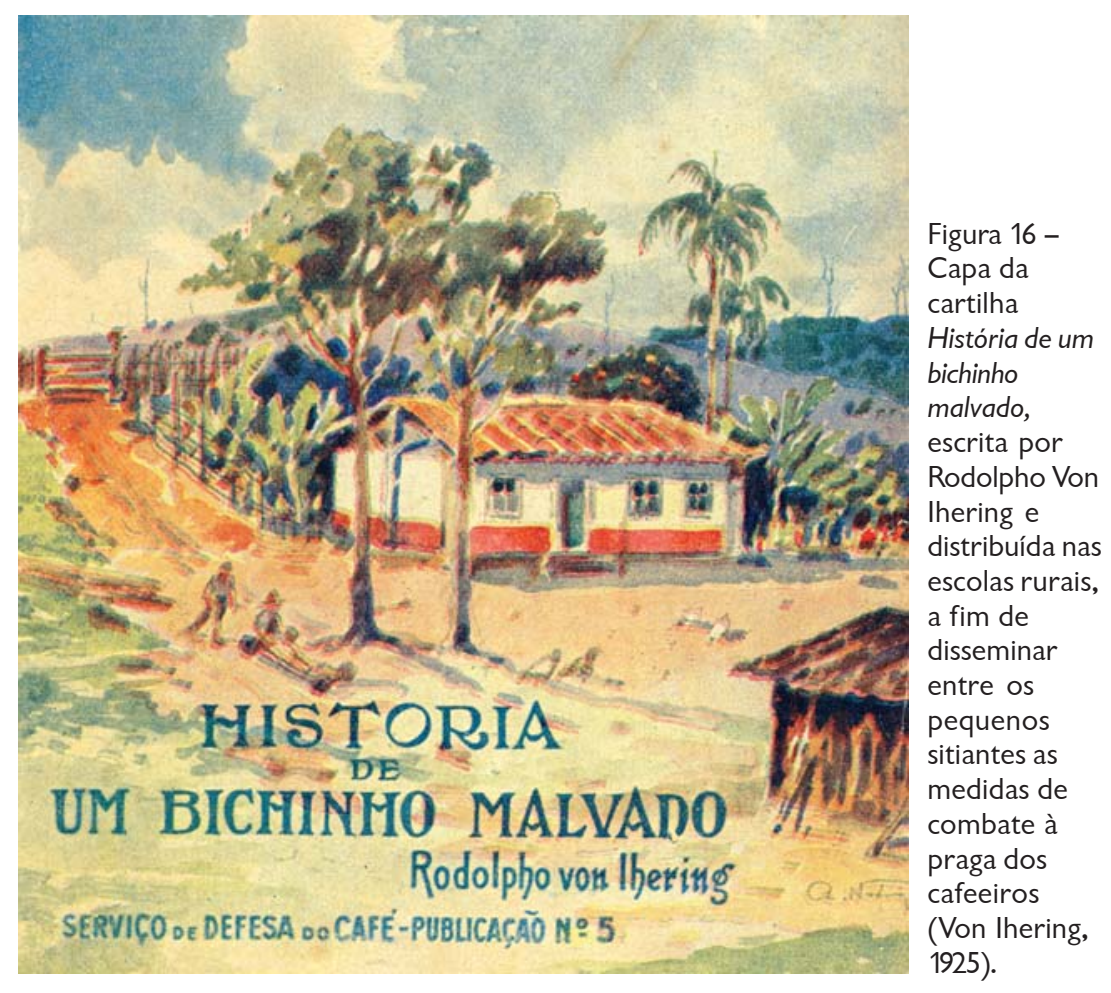


O naturalista Rodolpho von Thering, autor da cartilha e filho de Hermann von Thering, idealizador do Museu Paulista, punha em cena uma comunidade rural de pequenos lavradores às voltas com a praga. Ele ilustrava seu impacto na comunidade através de uma família dependente dos rendimentos de uma acanhada lavoura de café: a mulher, que teria de desistir dos passeios programados à capital, e o filho, que deixaria de ganhar um brinquedo muito desejado. Procurava-se sensibilizar a sociedade sobre os efeitos concretos da praga numa economia doméstica totalmente vinculada à pequena plantação de café.

Através de diálogos entre os personagens infantis da história, eram apresentadas noções gerais sobre os parasitas das plantas e frutas (Figura 17). Ao falar dos insetos que atacavam grãos como os do milho e do feijão, os populares 'carunchos', as crianças teciam comentários sobre o parasita que 'carunchava' o café e ameaçava a colheita de suas famílias (ibidem, p. 4-8). O pequeno sitiante às voltas com a broca-do-café, personagem central da história, teria tomado conhecimento das medidas de combate por meio de um amigo da família que o inteirara do assunto graças ao contato com um "grande quadro colorido" (ibidem, p. 13) afixado nos locais públicos. A cartilha idealizava uma situação em que os recursos de publicidade da Comissão atingiam efetivamente seus fins, ainda que indiretamente.

Tal qual o visconde de Sabu-

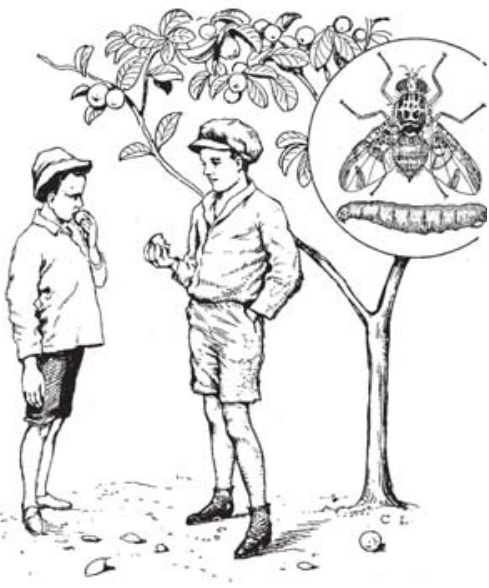

Figura 17 - llustração da cartilha História de um bichinho malvado, no qual se utilizam exemplos de parasitas de frutas, como o bicho da goiaba, para explicar como e por que ocorrem as pragas agrícolas (Von Ihering, 1925). gosa, de Monteiro Lobato, o personagem 'ilustrado' da historieta discorria sobre o inseto: sua metamorfose, modo de ataque, os efeitos na colheita e, o mais importante, os meios de combatê-lo. Como contraponto, passa a figurar na narrativa um personagem que arrogantemente desqualifica as medidas indicadas pelos cientistas. $\mathrm{O}$ desfecho que lhe é reservado é a completa ruína, ao passo que o protagonista consegue controlar a praga e tem brilhante colheita após observar os "conselhos da ciência" (ibidem, p. 3-9).

Distribuída aos alunos das escolas rurais, a cartilha teve tiragem de cinqüenta mil exemplares (Neiva, 1928, p. 11-2). No balanço feito três anos depois por Neiva (1928), ele consideraria eficaz essa estratégia de propaganda em virtude da queda significativa da praga nas pequenas propriedades, diferentemente das grandes, onde eram ainda observados altos índices de infestação. 
A estratégia de propaganda adotada pela Comissão foi sensível ao arranjo social da lavoura cafeeira, levando em conta a realidade dos pequenos proprietários, constituídos em sua maioria por excolonos.

As outras publicações da Comissão de Estudo e Debelação da Praga Cafeeira tiveram cunho mais técnico e destinavam-se aos pares ou a grupos sociais mais instruídos. Aos grandes proprietários eram dadas instruções e esclarecimentos sobre as medidas a serem tomadas. As comunicações voltadas para a comunidade de especialistas tratavam dos estudos sobre a praga em seus aspectos mais esotéricos. Incluíra, por exemplo, os do fitopatologista da Escola Agrícola de Piracicaba, Rosário Averna Saccá, sobre infecções de fungos e bactérias associadas ao ataque do café pelo Stephanoderes (Saccá, 1926a; 1926b).

A principal novidade daquela campanha de divulgação científica foi, contudo, a produção de um filme que exibia o modo de ataque do Stephanoderes e os meios de controlar sua disseminação. A película A Broca do café vulgarizou ao máximo, sobretudo entre os pequenos lavradores analfabetos ou "pouco amigo de leituras" (Pamplona, 1927, p. 4), os conhecimentos a respeito do inseto, de modo a suplantar o coro de "incrédulos", que duvidavam da existência da praga ou amenizavam sua importância ou, ainda, afirmavam já ter sido ela extinta.

Naquela conjuntura histórica o cinema constituía um meio muito avançado de comunicação de massa, com grande poder de arrebatamento e mobilização. Foi no pós-guerra que teve maior difusão no Brasil, ganhando popularidade sobretudo nas grandes cidades, onde suplantou o teatro como forma de lazer (Sevcenko, 1992, p. 92-3).

Para que o ataque do inseto ao grão de café fosse detalhadamente acompanhado nas telas, era necessário um aparato técnico que captasse imagens em pequenas, para não dizer minúsculas dimensões (Figura 18). A equipe responsável pela confecção do filme teve de fazer várias adaptações, já que não havia no Brasil os aparelhos necessários. Adotava-se, assim, a microcinematografia para fins de divulgação científica no Brasil (Pamplona, 1927, p. 6). A grande inovação representada pela microcinematografia consistiu na capacidade de manipulação do tempo dos fenômenos naturais, já que tornou possível vislumbrar, nas telas, eventos cuja longa duração não permitia que fossem apreciados em sua integridade ou com tanta eloqüência. Funda-se, assim, uma nova maneira de percepção dos experimentos encetados nos laboratórios e otimiza-se a forma de demonstração e, conseqüentemente, de prova (Landecker, 2006).

Foi necessário ainda adestrar os 'atores' para que atuassem perfeitamente diante das lentes, pois sob a luz intensa os besourinhos ficavam imóveis, inibidos pela claridade. O entomologista da Comissão, 
Manoel Lopes de Oliveira Filho, cuidou dos insetos, fazendo até mesmo a "toalete das larvas" com delicados pincéis que removiam a poeira acumulada sobre aquelas que provinham de depósitos (ibidem, p.7). A gravação de cenas externas para mostrar as medidas práticas que deviam ser tomadas pelos lavradores, no campo, foi dirigida por Adalberto Queiroz Telles.

O filme terminava com imagens da capital paulista, a 'metrópole do café', relacionando sua pujança material e sua soberba urbanização aos louros da cafeicultura (Figura 19). Amensagem era clara: tudo aquilo que os paulistas ostentavam como símbolos de seu progresso e dinamismo era ameaçado pelo personagem aparentemente insignificante que havia protagonizado o enredo daquela película. Urgia que a lavoura se mobilizasse para acatar os conselhos dos cientistas se quisesse preservar seu poder econômico e sua primazia.

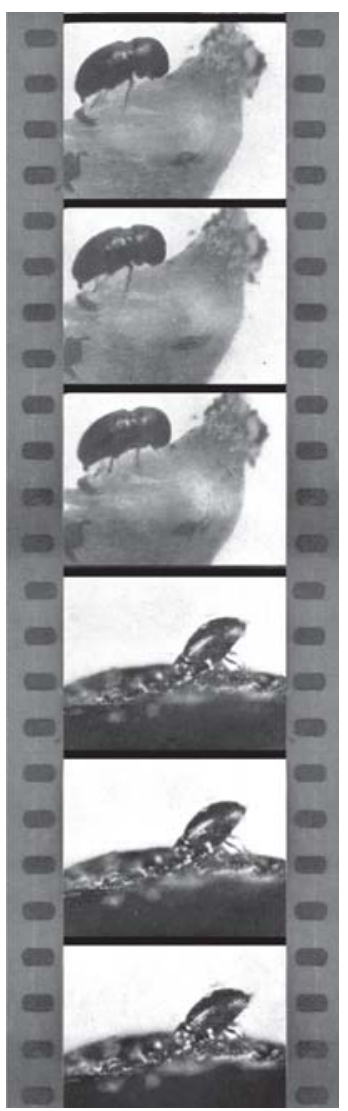

Figura 18 - Imagem da película A Broca do café, exibida em vários cinemas do interior paulista (Oliveira Filho, 1927).

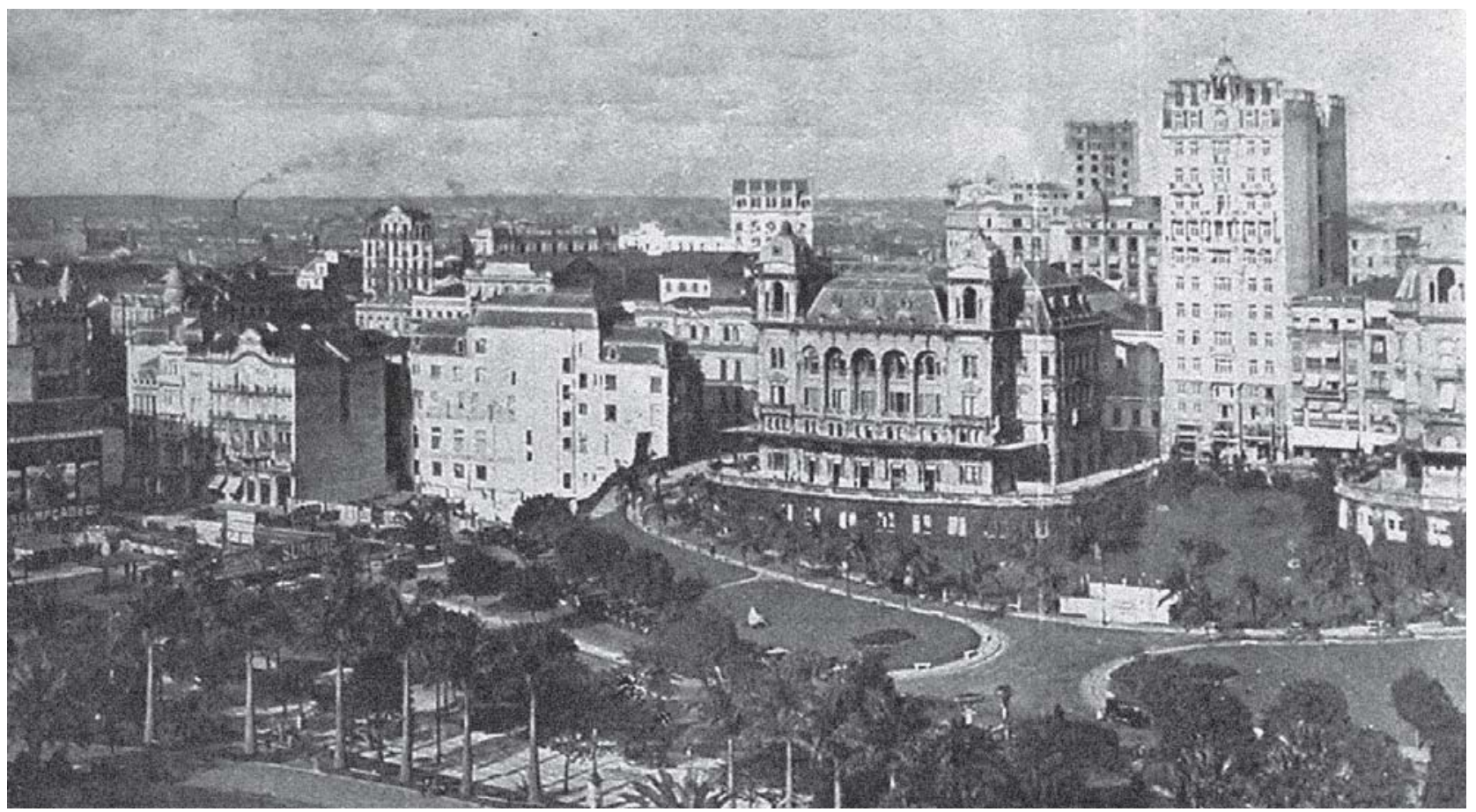

Figura 19 - Imagem do centro de São Paulo nos anos 20, exibida no filme A Broca do café, com o fito de vincular a pujança material paulista aos louros da cafeicultura (Pamplona, 1927). 
A distribuição e divulgação do filme foram feitas por viajantes munidos de cartas de recomendação assinadas por Neiva. Nas cidades do interior, travavam contato com as autoridades locais e convidavam os fazendeiros a assistir à exibição pública da película (Figura 20). Levavam ainda material impresso de divulgação das medidas de combate à broca (ibidem, p. 9). Algumas exibições foram feitas nas próprias fazendas.

Os números atestam a repercussão de $A$ Broca do café, produzido pela Independência Omnia Film: ao todo, foram 232 sessões do filme assistidas por 104.634 pessoas, com distribuição de cinqüenta mil opúsculos e dez mil cartazes (ibidem, p. 12).

Os textos impressos foram mantidos durante toda a campanha. A publicação de número 20, Contribuição para o conhecimento da broca do café Stephanoderes hampei, escrita por Oliveira Filho (1927), foi o mais completo estudo sobre o parasita até então publicado. $\mathrm{O}$ autor compilava o conhecimento produzido pelo laboratório de entomologia sobre a biologia do inseto e os meios de combatê-lo. Eram minuciosas as descrições da morfologia, taxonomia, comportamento, meios de disseminação, inimigos naturais e outros aspectos do parasita. Apesar da riqueza de detalhes, Oliveira Filho advertia, logo de início, que não se tratava de uma publicação direcionada a seus pares:

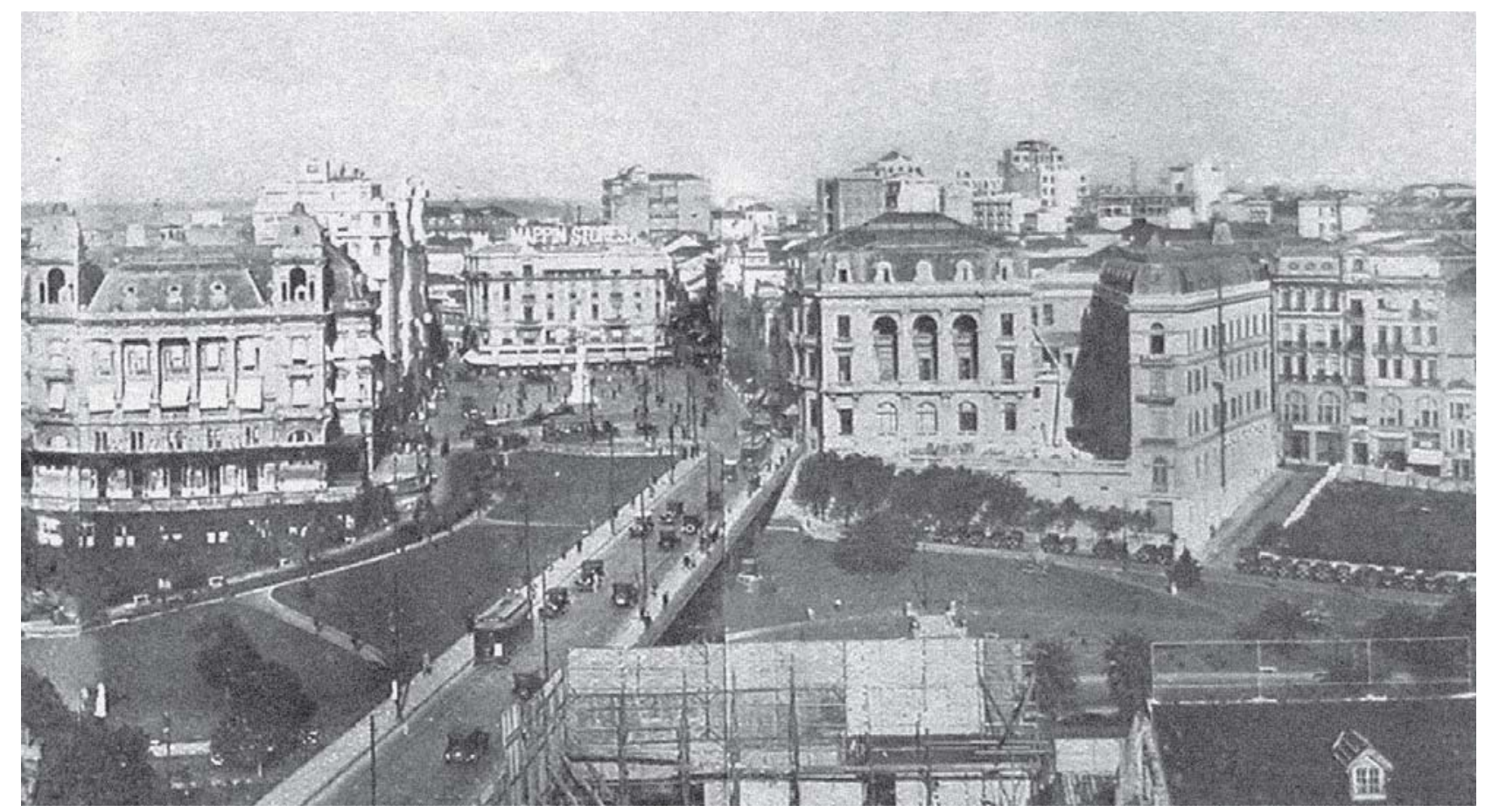


Adotamos neste trabalho, muito de caso pensado, uma forma de exposição em linguagem corrente, fugindo o quanto possível à secura da terminologia científica, com a intenção de divulgar a biologia da broca em uma esfera maior do que à limitada aos especialistas. (Oliveira Filho, 1927, p. 3)

Através da campanha de divulgação, os cientistas fizeram ecoar sua voz por todas as paragens da zona produtora paulista. Procuraram corrigir o "desvio de mentalidade" - para citar uma expressão de Neiva - dos que não acatavam os ditames da ciência. Combinando coerção e persuasão, a campanha capitaneada por Neiva certamente inspirou-se nas lições proporcionadas por aquela liderada por seu 'mestre', Oswaldo Cruz, na capital republicana, no começo

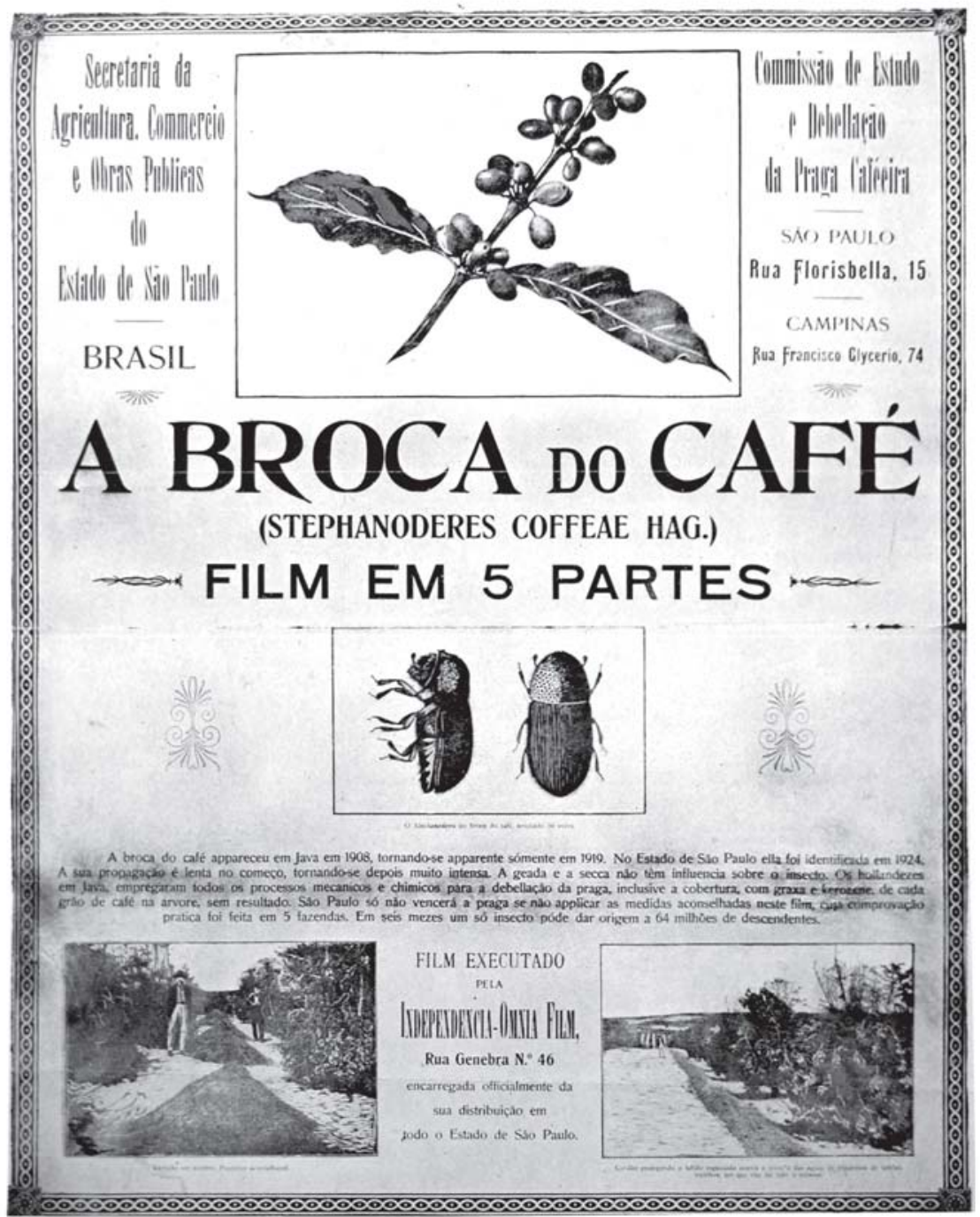

Figura 20 - Cartaz de divulgação do filme A Broca do café, distribuído pelos propagandistas contratados pela Comissão para viajar pelo interior paulista (Pamplona, 1927). 
do século, quando Neiva, recém-formado, iniciou sua carreira como sanitarista e cientista. Os Conselhos ao Povo publicados pelo diretorgeral de Saúde Pública, em 1903-1905, não foram suficientes para neutralizar as reações que culminaram na Revolta da Vacina. (Benchimol, 1990, p. 18). Analisando-se, comparativamente, vê-se que o pólo da persuasão teve peso e sofisticação bem maior na campanha fitossanitária liderada agora por Arthur Neiva, sabedor dos conflitos enfrentados pelo sanitarista.

\section{O desenlace da campanha: "A broca é civilizadora"}

As ações da Comissão prolongaram-se pelos anos de 1925, 1926 e 1927. Queda significativa nos níveis de infestação e no número de municípios contaminados foi observada a partir de agosto de 1925. Acreditou-se que a praga estivesse sob controle, e Neiva chegou a admitir até mesmo a hipótese de que fosse extinta. Durante 1926, a retórica da campanha adquiriu tom triunfalista. Entre 1925 e 1927, o número de municípios contaminados oscilou entre 11 e 14, bem menor do que os 42 observados em abril de 1925. Certamente, a maior extensão do aparato fiscalizador, fortalecido pelas medidas coercitivas instituídas pela Lei 2.020, de dezembro de 1924, concorreu para o aumento da observância das práticas recomendadas pela Comissão. Introduziram-se alterações na dinâmica de produção do café, de modo que práticas até então desconhecidas passaram a fazer parte do cotidiano das fazendas.

Os cientistas retrataram a praga como um alerta e uma oportunidade para que os fazendeiros abandonassem métodos predatórios de cultivo habituais na cafeicultura em prol de uma atitude de maior zelo e racionalidade. A propaganda passou a distinguir 'lavrador' e 'agricultor'. O lavrador, identificado com o atraso, agia sem pensar, ao passo que o agricultor, representante da modernidade, pensaria para agir. O primeiro, aferrado às tradições, procederia por instinto hereditário, estorvando o agricultor:

A lavoura é a parte mecânica da agricultura, é o braço, não o cérebro. A lavoura é uma arte que se imita, a agricultura é uma ciência que se estuda ... O arado é o símbolo da lavoura, o livro, o da agricultura. O campo experimental e o laboratório criam o agricultor. (O Estado de S. Paulo, 4.12.1924)

Para 'criar o agricultor', os cientistas colocavam-se como os arautos da civilização e da modernidade, capazes de levar ao campo valores caros à sociedade ocidental da época, sobretudo a ciência, a motriz do processo de modernização agrícola. A prática da lavoura extrativista deveria ser abandonada a favor de uma agricultura racional e sistemática. Segundo o discurso da Comissão, ao trazer para o campo a ciência, a broca trazia também a 'civilização': 


\begin{abstract}
A broca é civilizadora. Vem obrigar os fazendeiros pessoalmente ou pelos olhos dos seus distraídos administradores a repararem nas árvores para, por meio de um zelo racional, corrigir os seus defeitos ... transformando a indústria de colher café em lavoura baseada em regras da agricultura ... Ela parece um protesto contra o pouco caso que os fazendeiros fazem do cafeeiro e contra o descuido dos nossos governos, que conservam nossos portos escancarados para receberem tantas pragas da agricultura. (O Estado de S. Paulo, 19.2.1925)
\end{abstract}

O aumento das prerrogativas da Comissão, que já não se limitavam a estudos sobre a broca, suscitou, em fins de 1926, o debate sobre a criação de uma instituição permanente. Os problemas crescentes com pragas agrícolas justificavam a fundação de um instituto científico voltado para a defesa agrícola. Karl Escherich, entomologista da Universidade de Munique, ao visitar São Paulo em 1926, endossou a necessidade de um Instituto de Entomologia Aplicada cujo ponto de partida seria a Comissão ( $O$ Estado de $S$. Paulo, 30.3.1926).

O projeto do Instituto Biológico de Defesa Agrícola esboçado por Arthur Neiva foi apresentado à Câmara dos Deputados em 16 de dezembro de 1926. As associações agrícolas paulistas - Sociedade Paulista de Agricultura, Sociedade Rural Brasileira e Liga Agrícola Brasileira - fizeram lobby em favor do projeto, que, apesar disso, não foi aprovado. A derrota foi qualificada como sinal do descaso do governo paulista com as ciências. Em "atmosfera antipática a seus membros", a estrutura técnico-científica de São Paulo era apontada como decadente em praticamente todas as esferas, com a evasão de vários personagens outrora importantes para a ciência paulista, como Vital Brasil, que em 1918 deixou a direção do Instituto Butantan para fundar no ano seguinte, em Niterói, o Instituto de Higiene, Soroterapia e Veterinária, atual Instituto Vital Brasil, por ele dirigido até sua morte (Benchimol \& Teixeira, 1993). Logo que a praga viera a lume, Manoel Lopes de Oliveira Filho afirmara em O Estado de S. Paulo (14.6.1924):

São Paulo vai progredindo materialmente e retrogradando sob o ponto de vista das ciências e das artes puras e aplicadas. Progresso utilitário sem o progresso intelectual não é adiantamento sólido; a geração-cogumelo dos rapidamente enriquecidos rapidamente é, na sua grande maioria, de crassa ignorância.

Em dezembro de 1927, o projeto da instituição de pesquisa agrícola foi reapresentado à Câmara, incluindo, além da defesa fitossanitária, uma seção de defesa animal. Agora, seria contemplada não apenas a agricultura, mas também a pecuária. Em 26 daquele mês, através da Lei 2.243, foi criado o Instituto Biológico de Defesa Agrícola e Animal. Ficava extinta a Comissão de Estudo e Debelação 
da Praga Cafeeira, mas na prática a maior parte de seus membros passou a compor os quadros do novo instituto, cuja principal incumbência, ou a mais imediata, era zelar pela defesa fitossanitária do café e levar adiante a campanha contra a broca.

O Instituto Biológico foi apresentado pelos próceres da ciência como o coroamento da 'regeneração' da ciência paulista iniciado pela Comissão. Teria sido ela a responsável por estender ao terreno econômico o espectro de ação da ciência, ao ultrapassar as cercas das fazendas e interferir diretamente no processo produtivo. Assim como na saúde pública, a lógica campanhista militar alcançou o campo com o fito de 'civilizá-lo'. Respeitadas as especificidades, na saúde pública paulista esse processo teria começado com a implementação do Código Sanitário Rural em 1918.

Apesar de não se tratar de uma epidemia, o combate à broca foi balizado pelo modelo campanhista da saúde pública estruturado na virada do século XIX para o XX. Como dissemos, foi muito importante o fato de Arthur Neiva, chefe da Comissão, ter iniciado sua trajetória profissional, como médico, no serviço de profilaxia da febre amarela, participando, em seguida, de diversas campanhas contra a malária e do enfrentamento da gripe espanhola, em 1918, quando era diretor do Serviço Sanitário paulista (Borgmeier, 1940; Benchimol \& Teixeira, 1993).

A campanha contra a broca foi responsável pela instauração de vigoroso aparato de pesquisa em São Paulo, que mais à frente implementaria métodos pioneiros no combate a pragas, como o controle biológico. A campanha foi um marco crucial no Brasil tanto na institucionalização da pesquisa agrícola como na história da divulgação científica, ao lançar mão de estratégias elaboradas de vulgarização do conhecimento produzido nos laboratórios. A história de uma praga como a broca-do-café, da qual o presente artigo recupera um ínfimo capítulo, permite entrever quão imbricados se tornam os domínios da economia, da política e da ciência. As pragas agrícolas constituem, assim, relevantes objetos de reflexão histórica por permitir aprofundar o debate sobre as relações entre ciência e sociedade e lançar luz sobre conturbados contextos históricos como o de São Paulo na década de 1920.

\section{REFERÊNCIAS BIBLIOGRÁFICAS}

Benchimol, Jaime Larry 2001

Benchimol, Jaime Larry 1999

Benchimol, Jaime Larry 1990
Febre amarela, a doença e a vacina: uma história inacabada. Rio de Janeiro: Fiocruz.

Dos micróbios ao mosquito: febre amarela e revolução pasteuriana no Brasil. Rio de Janeiro: Fiocruz/UFRJ.

Manguinhos do sonho à vida: a ciência na Belle Époque. Rio de Janeiro: Fiocruz. 
Benchimol, Jaime Larry; Sá, Magali Romero (org.) 2006

Benchimol, Jaime Larry; Teixeira, L. A. 1993

Berthet, Jean Jules Arthaud

Bloch, P. 1968

Borgmeier, T. 1940

Britto, N. 1995

Castro Santos, L. A. 1987

Comissão de Estudo e Debelação da Praga Cafeeira 1925

Domingues, H. M. B. 1995

Freire, $\mathrm{H}$. 1928

Furtado, $\mathrm{C}$. 1968

Howard, L. O 1930

Hucke, $\mathrm{O}$. 1925

Landecker, $\mathrm{H}$. 2006

Lapa, J. R. A 1983

Latour, B. 2000

Latour, B. 1995

Love, J. 1982

Martini, A. J. 2004
Adolpho Lutz, Obra Completa: Entomologia/Entomology.

Rio de Janeiro: Fiocruz, v. II, livro 2. (no prelo)

Cobras, lagartos e outros bichos: uma história comparada dos Institutos Oswaldo Cruz e Butantan. Rio de Janeiro: Fiocruz/UFRJ.

Caruncho do café: informação prestada pelo Snr. Director do Institucto Agronômico a respeito de amostras de café vindas do Congo Belga. Boletim de agricultura, n. 5, 14ª série, p. 312-3.

Vida e obra de Ângelo Moreira da Costa Lima: vulto da ciência brasileira. Rio de Janeiro: Conselho Nacional de Pesquisas.

Arthur Neiva: a propósito do seu 60o aniversário natalício. Revista de entomologia, Rio de Janeiro, v. 11, fasc. 1-2.

Oswaldo Cruz: a construção de um mito na ciência brasileira. Rio de Janeiro: Fiocruz.

Power, ideology and public health in Brazil (1889-1930). PhD Thesis, Harvard University.

Comissão de Estudo e Debelação da Praga Cafeeira: lei, decreto e regulamento. São Paulo: Secretaria da Agricultura, Commercio e Obras Publicas.

Ciência: um caso de política. As relações entre as ciências naturais e a agricultura no Brasil-Império. Tese de doutoramento, FFLCH/USP, São Paulo.

A praga do café em São Paulo: seus males, suas origens e seus remédios. São Paulo: Imprensa Oficial.

Formação econômica do Brasil. 8. ed. São Paulo: Cia. Ed. Nacional.

A history of applied entomology. Washington (DC): Smithsonian Institution.

Expurgo de saccaria em São Paulo contra a broca do café. Posto de Expurgo n. 2. São Paulo: Secretaria da Agricultura, Commercio e Obras Publicas.

Microcinematography and the history of science and film. Isis, v. 97, n. 1, p. 121-33.

A economia cafeeira. São Paulo: Brasiliense.

Ciência em ação: como seguir cientistas e engenheiros sociedade afora. São Paulo: Ed. Unesp.

Dádme un laboratorio y moveré el mundo. In: Iranzo et al. Sociologia de la Ciencia y de la Tecnologia. Madrid: Consejo Superior de Investigaciones Cientificas, p. 237-57.

A locomotiva: São Paulo na Federação Brasileira - 1889-1937.

Rio de Janeiro: Paz e Terra.

O plantador de eucaliptos: a questão da preservação florestal no Brasil e o resgate documental do legado de Edmundo Navarro de Andrade.

Dissertação de Mestrado, São Paulo, FFLCH/USP. 
Mattos, O. N.

1990

Neiva, A. 1928

Neiva, A.; Andrade,

E. N.; Telles, A. Q. 1925a

Neiva, A.; Andrade, E. N.; Telles, A. Q. $1925 b$

Neiva, A.; Costa Lima,

A. M.; Andrade, E. N. 1924

Novaes, C. 1922

Oliveira Filho, M. L. 1927

Oliver, G. S. 2001

Pamplona, A. 1927

Rodovalho, B. T. 1925

Saccá, R. A. $1926 a$

Saccá, R. A. $1926 b$

Sevcenko, N. 1992

Silva, S. 1995

Taunay, A. d'E. 1945

Telarolli Jr., R. 1996a

Telarolli Jr., R. 1996b

Von Ihering, R. 1925
Café e ferrovias: a evolução ferroviária de São Paulo e o desenvolvimento da cultura cafeeira. Campinas: Pontes.

Os trabalhos da Comissão de Estudo e Debelação da Praga Cafeeira desde seu início. Relatório apresentado ao Snr. Fernando Costa, secretário da Agricultura, Industria e Comercio. São Paulo: Secretaria da Agricultura, Industria e Commercio.

A broca do café: collectanea de communicados à imprensa.

Agosto-Dezembro de 1924. São Paulo: Secretaria da Agricultura, Commercio e Obras Publicas.

A broca do café: $2^{2}$ collectanea de communicados à imprensa. Janeiro-Junho de 1924. São Paulo: Secretaria da Agricultura, Commercio e Obras Publicas.

Relatório da Comissão Technica sobre a broca do café (Stephanoderes coffeae Hag.). São Paulo: Secretaria de Agricultura, Commercio e Obras Publicas.

Um novo broqueador do cafeeiro: Xyleborus coffeicola N. sp. Fam Ipidae. In: Boletim de Agricultura, série 23, mar.-abr., n. 3 e 4, p. 67-70.

Contribuição para o conhecimento da broca do café Stephanoderes hampei (Ferr, 1867): modo de comportar-se e de ser combatida em São Paulo. São Paulo: Secretaria da Agricultura, Industria e Commercio.

José Vizioli e o início do processo de modernização da agroindústria canavieira paulista, 1919-1949. Dissertação de Mestrado, Campinas, IG/Unicamp.

Divulgação, pelo cinema, dos methodos de combate à broca do café no estado de São Paulo. São Paulo: Secretaria da Agricultura, Commercio e Obras Publicas.

$O$ repasse e seus resultados.

São Paulo: Secretaria da Agricultura, Commercio e Obras Publicas.

As manifestações pathologicas que acompanham o desenvolvimento da broca Stephanoderes hampei (Ferr) ou Stephanoderes coffeae (Hag.) nos fructos ou nas sementes. São Paulo: Secretaria da Agricultura, Commercio e Obras Publicas.

Algumas moléstias cryptogamicas novas do systema radicular do cafeeiro. São Paulo: Secretaria da Agricultura, Commercio e Obras Publicas.

Orfeu extático na metrópole: São Paulo sociedade e cultura nos frementes anos 1920. São Paulo: Companhia das Letras.

Expansão cafeeira e origens da indústria no Brasil.

8. ed. São Paulo: Alfa-Ômega.

Pequena história do café no Brasil.

Rio de Janeiro: Departamento Nacional do Café.

Imigração e epidemias no estado de São Paulo.

In: História, Ciências, Saúde - Manguinhos, Rio de Janeiro, v. 3, n. 2, p. 265-83

Imprensa e Saúde Pública no Estado de São Paulo no século XIX. In: Revista de História, São Paulo, n. 15, p. 267-85.

Histórias de um bichinho malvado.

São Paulo: Secretaria da Agricultura, Commercio e Obras Publicas. 


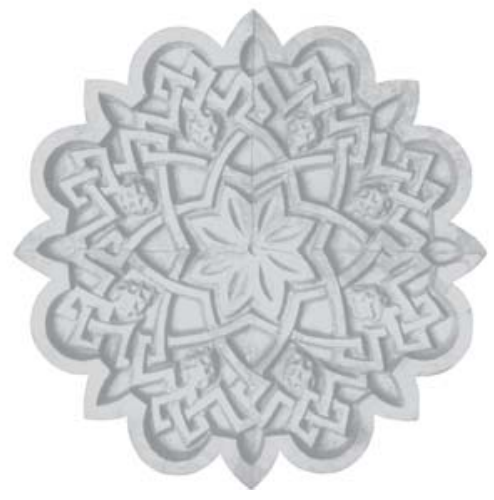

